University of Louisville

ThinkIR: The University of Louisville's Institutional Repository

Electronic Theses and Dissertations

$12-2018$

\title{
Particulate hexavalent chromium does not induce centrosome amplification in sperm whale and bowhead whale cells.
}

Jennifer Haruka Toyoda

University of Louisville

Follow this and additional works at: https://ir.library.louisville.edu/etd

Part of the Pharmacology, Toxicology and Environmental Health Commons

\section{Recommended Citation}

Toyoda, Jennifer Haruka, "Particulate hexavalent chromium does not induce centrosome amplification in sperm whale and bowhead whale cells." (2018). Electronic Theses and Dissertations. Paper 3133.

https://doi.org/10.18297/etd/3133

This Master's Thesis is brought to you for free and open access by ThinkIR: The University of Louisville's Institutional Repository. It has been accepted for inclusion in Electronic Theses and Dissertations by an authorized administrator of ThinkIR: The University of Louisville's Institutional Repository. This title appears here courtesy of the author, who has retained all other copyrights. For more information, please contact thinkir@louisville.edu. 
PARTICULATE HEXAVALENT CHROMIUM

DOES NOT INDUCE CENTROSOME AMPLIFICATION IN

SPERM WHALE AND BOWHEAD WHALE CELLS

\author{
By \\ Jennifer Haruka Toyoda \\ B.A., University of Massachusetts Amherst, 2005 \\ B.S., University of Kentucky, 2011

\begin{abstract}
A Thesis Submitted to the Faculty of the School of Medicine of the University of Louisville in Partial Fulfillment of the Requirements of the Degree of

Master of Science

in Pharmacology and Toxicology
\end{abstract} \\ Department of Pharmacology and Toxicology \\ University of Louisville \\ Louisville, Kentucky \\ December 2018
}


Copyright 2018 by Jennifer Haruka Toyoda

All rights reserved 

PARTICULATE HEXAVALENT CHROMIUM DOES NOT INDUCE CENTROSOME AMPLIFICATION IN SPERM WHALE AND BOWHEAD WHALE CELLS

By

Jennifer Haruka Toyoda

B.A., University of Massachusetts Amherst, 2005

B.S., University of Kentucky, 2011

A Thesis Approved on

July 26, 2018

By the following Thesis Committee:

John Pierce Wise, Sr.

Sandra S. Wise

J. Christopher States

Levi J. Beverly

Chendil Damodaran

Gary Hoyle 


\title{
ABSTRACT
}

\author{
PARTICULATE HEXAVALENT CHROMIUM \\ DOES NOT INDUCE CENTROSOME AMPLIFICATION \\ IN SPERM WHALE AND BOWHEAD WHALE CELLS
}

Jennifer Toyoda

July 26, 2018

Hexavalent chromium [Cr(VI)] is a widespread environmental and occupational carcinogen. The mechanism of carcinogenesis remains poorly understood, but chromosome instability (CIN) is the dominant theory. How numerical CIN arises is unclear, but it correlates with centrosome amplification. Both phenotypes are hallmarks of cancers, early events in carcinogenesis, and have been shown to occur after $\mathrm{Cr}(\mathrm{VI})$ exposure to human skin and lung fibroblasts. In this study, we investigate numerical CIN and centrosome amplification in whale cells. Whales are our closest marine relatives, have long lifespans, and are exposed to environmental $\mathrm{Cr}(\mathrm{VI})$. Importantly, they have low cancer rates and cell culture studies show they are resistant to $\mathrm{Cr}(\mathrm{VI})$ genotoxicity. 
This study found increasing concentrations and prolonged exposure to zinc chromate produced no increase in aneuploid metaphases or centrosome amplification in interphase or mitotic cells. A concentration-dependent increase in cytotoxicity was measured, but no change in relative survival occurred with prolonged exposure. 


\section{TABLE OF CONTENTS}

PAGE

ABSTRACT iii

LIST OF FIGURES vii

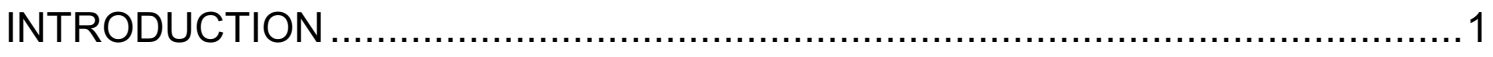

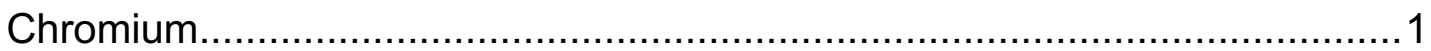

Chromosome Instability as a Carcinogenic Mechanism ........................ 5

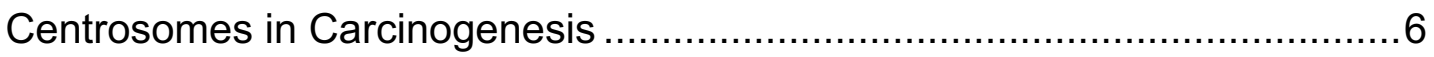

Whales as a Model Species for Environmental Toxicology ...................... 10

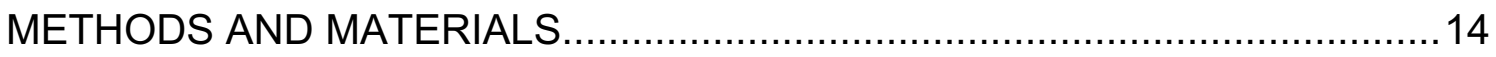

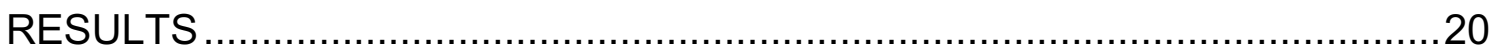

Particulate Hexavalent Chromium is Cytotoxic to Whale Cells..................20

Cr(VI) Does Not Induce Spindle Assembly Checkpoint Bypass

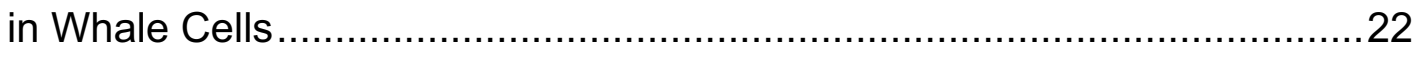

Whale Cells are Resistant to $\mathrm{Cr}(\mathrm{VI})$-Induced Aneuploidy ......................24

$\mathrm{Cr}(\mathrm{VI})$ Does Not Induce Centrosome Amplification

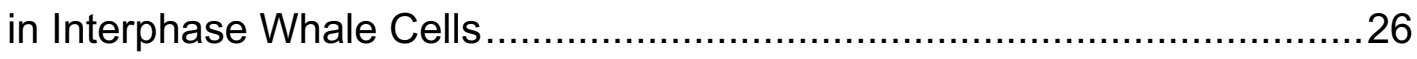

$\mathrm{Cr}(\mathrm{VI})$ Does Not Induce Centrosome Amplification in Mitotic Whale Cells .. 28

Chromium Uptake Differs Between Sperm Whale and

Bowhead Whale Cells 30 


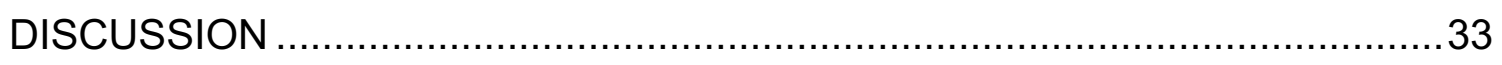

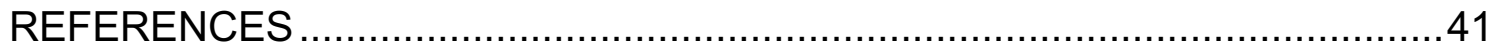

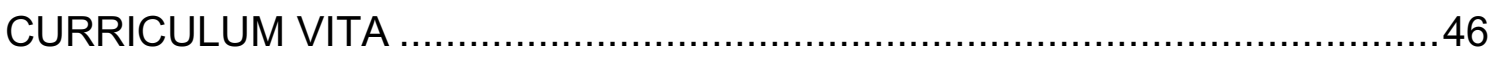




\section{LIST OF FIGURES}

PAGE

1. Relative Survival of Sperm Whale Skin Fibroblasts..................................21

2. Relative Survival of Bowhead Whale Lung Fibroblasts ...........................21

3. Spindle Assembly Checkpoint Bypass in Sperm Whale Cells ....................23

4. Spindle Assembly Checkpoint Bypass in Bowhead Whale Cells ................24

5. Aneuploidy in Sperm Whale Metaphases ............................................25

6. Aneuploidy in Bowhead Whale Metaphases ….....................................26

7. Centrosome Amplification in Sperm Whale Interphase Cells ...................27

8. Centrosome Amplification in Bowhead Whale Interphase Cells .................28

9. Centrosome Amplification in Sperm Whale Mitotic Cells ..........................29

10. Centrosome Amplification in Bowhead Whale Mitotic Cells .......................30

11. Intracellular Chromium Concentration in Sperm Whale Cells......................31

12. Intracellular Chromium Concentration in Bowhead Whale Cells ................32 


\section{INTRODUCTION}

\section{Chromium}

Due to their chemical and physical advantages, metals are widely used in industry. As production and use of metals increase, waste, by-products, and leaching from commercial products continues to pose a significant environmental health risk. Most heavy metals have serious toxic potential and induce cancer and disease. Despite their well-known toxic effects, the mechanism of metalinduced carcinogenesis remains poorly understood. Metals are listed as five of the eight most important occupational lung carcinogens identified by the World Health Organization (WHO) and the International Agency for Research on Cancer (IARC) (Driscoll, 2004).

Hexavalent chromium $[\mathrm{Cr}(\mathrm{VI})]$ is a category 1 carcinogen recognized by IARC and is listed among the top 20 on the Agency for Toxic Substances and Disease Registry (ATSDR) Substance Priority List. In 2006, OSHA reduced limits of occupational $\mathrm{Cr}(\mathrm{VI})$ exposure to $5 \mu \mathrm{g} / \mathrm{m}^{3}$ of air. $\mathrm{Cr}(\mathrm{VI})$ has been studied in occupational settings since 1948, however environmental exposure also presents a risk to humans and wildlife. 
Chromium enters the environment through natural processes such as erosion and volcanic eruption, but the majority of hexavalent chromium contamination is due to anthropogenic sources. Chromate compounds have broad industrial usage including pigment production, paints, anti-corrosives, leather tanning, wood preservatives, cement mixtures, electroplating, stainless steel welding, and metal processing. Contamination arises from manufacturing wastes, mining waste, toxic dust, and degradation of paints and coatings (Jacobs \& Testa, 2005; National Institute for Occupational Safety and Health, 2013). $\mathrm{Cr}(\mathrm{VI})$ exposure can occur through dermal contact or ingestion of contaminated water or soil as well as inhalation of mists and dust, although evidence suggests that exposure by ingestion is less carcinogenic. Common sources of occupational exposure are welding fumes, pigment and alloy dusts, and primer sprays, which pose dangerous risks due to the concentrations, durations, and route of exposure. In the United States, industrial sources release up to 2,900 tons of chromium into the atmosphere (Agency for Toxic Substances and Disease Registry, 2012) and total global atmospheric emission is estimated at 58,000 to 112,000 tons per year (Johnson, Schewel, \& Graedel, 2006). Approximately one third of these emissions are in the hexavalent state (Johnson et al., 2006).

Chromium exists in valence states from chromium (II) to chromium (VI). The trivalent and hexavalent forms are environmentally stable and biologically relevant. Trivalent chromium readily binds to extracellular molecules and is prevented from entering cells. However, due to structural mimicry of phosphate 
and sulfate, hexavalent chromium enters cells via facilitated diffusion through anion channels and is considered the most toxic valence state. Chromium damages cells by two approaches. First, inside the cell $\mathrm{Cr}(\mathrm{VI})$ is rapidly reduced to $\mathrm{Cr}(\mathrm{III})$ by agents such as ascorbate and glutathione, producing reactive oxygen species through fenton-like reactions. Secondly, $\mathrm{Cr}(\mathrm{III})$ binds to intracellular molecules, creating DNA and protein adducts. Bound $\operatorname{Cr}(I I I)$ is unable to leave the cell or penetrate the plasma membrane (Occupational Safety and Health Administration, 2006). Intracellular depletion of $\mathrm{Cr}(\mathrm{VI})$ by reduction favors increasing $\mathrm{Cr}(\mathrm{VI})$ diffusion into the cell. Chromium-biomolecule complexes have been implicated in causing protein interference as well as severe DNA damage.

Hexavalent chromium is a potent carcinogen, as demonstrated by numerous epidemiological, animal, and cell culture studies. High rates of lung cancer have been observed in chromate pigment workers since the 1930s (Levy, Martin, \& Bidstrup, 1986). Follow up studies of workers employed at a Norwegian zinc chromate pigment plant between 1948 and 1972 show that 6 of 24 workers employed over 3 years, and 6 of 18 workers exposed for over 5 years developed bronchial carcinomas, in excess of the expected local rates (Langard \& Vigander, 1983). Intrabronchial pellet implantation of hexavalent chromates in rat lungs produced bronchial carcinomas and demonstrated the carcinogenic potential of several species of $\mathrm{Cr}(\mathrm{VI})$ (Levy et al., 1986). Cell culture studies show that $\mathrm{Cr}(\mathrm{VI})$ causes DNA breaks, suppresses DNA repair, and contributes to aneuploidy (Holmes, Wise, \& Wise, 2008; S. S. Wise \& Wise, 2012). Particulate $\mathrm{Cr}(\mathrm{VI})$ 
caused loss of contact inhibition and anchorage-independent growth in human lung fibroblasts (Xie, Wise, \& Wise, 2008) and human lung epithelial cells (Xie et al., 2007).

Hexavalent chromates range in solubility. Fully soluble chromates such as sodium chromate are considered less toxic than insoluble chromates such as lead chromate. Differences in toxicity seem to relate to the residence time and elimination time of the various compounds. Particulate $\mathrm{Cr}(\mathrm{VI})$ has been shown to lodge at bronchial bifurcation sites where they persist and release ions over a long period of time (Agency for Toxic Substances and Disease Registry, 2012; Occupational Safety and Health Administration, 2006). The efficiency of particle elimination by the mucocilliary escalator depends on the size of the particle, location of deposition, and the health of the individual (Occupational Safety and Health Administration, 2006). Soluble compounds are absorbed more quickly and thus soluble chromate levels in the lung decrease more rapidly than particulate chromates (Occupational Safety and Health Administration, 2006). Slightly soluble compounds such as zinc chromate have been shown to be more potent than soluble sodium chromate or insoluble lead chromate in rodent studies (Occupational Safety and Health Administration, 2006). Compounds classified as "slightly soluble" possess the particulate nature that incurs long residence times in the lung, but increased solubility that causes greater local ion concentrations than less soluble particulates (Occupational Safety and Health Administration, 2006). Particulate chromate has been shown to be more genotoxic than soluble 
chromate in sperm whale cells as well (J. P. Wise, Sr., Wise, LaCerte, Wise, \& Aboueissa, 2011).

\section{Chromosome Instability as a Carcinogenic Mechanism}

The dominant theory of carcinogenic action by $\mathrm{Cr}(\mathrm{VI})$ is chromosome instability (CIN). CIN entails structural damage, such as chromosome breaks and translocations, and numerical instability characterized by the loss or gain of entire chromosomes. After $\mathrm{Cr}(\mathrm{VI})$ is reduced to $\mathrm{Cr}(\mathrm{III})$ within the cell, $\mathrm{Cr}(\mathrm{III})$ binds to biomolecules causing DNA-Cr-DNA bridges and DNA-Cr-protein complexes. These deformations cause DNA polymerase stalling at replication forks and induce double strand breaks. Additionally, attempts at repairing adducts results in the creation of DNA breaks that overwhelm the cell's compromised repair machinery. How numerical instability arises is not fully understood but it is known that mitotic disruption causes mis-segregation of chromosomes to daughter cells.

Aneuploidy is the most common form of CIN in cancers (Brinkley, 2001). The gain or loss of chromosomes causes gene imbalances which perturb pathways critical to genomic stability, such as DNA repair, cell cycle regulation, and DNA segregation. Rate of tumor progression is influenced by dramatic shifts in ratios of tumor suppressor genes or oncogenes incurred by chromosome gains and losses (Fukasawa, 2005).

Aneuploidy is usually caused by chromosome segregation errors, which result from failure of cytokinesis, or from mitotic disruptions such as loss of checkpoint control, kinetochore attachment errors, and centrosome amplification 
(Fukasawa, 2005). Centrosome amplification has been observed in most solid and hematological cancers (Chan, 2011). Cell culture studies show that it is correlated with aneuploidy (S. S. Wise \& Wise, 2010). Levine, et al., (2017) used inducible Plk4 overexpression to generate supernumerary centrosomes in a mouse model (Levine et al., 2017). Experimental centrosome amplification was sufficient to cause aneuploidy and spontaneous tumors. Relevant to this study, $\mathrm{Cr}(\mathrm{VI})$ causes aneuploidy in human lung fibroblasts with increased exposure times and concentrations (Holmes et al., 2006; Martino, Holmes, Xie, Wise, \& Wise, 2015). Cr(VI)-treated human lung cells show increased rates of aberrant mitosis and centrosome amplification (Holmes et al., 2006).

$\mathrm{Cr}(\mathrm{VI})$-transformed BEP2D cells, identified by loss of contact inhibition and gain of anchorage-independent growth, exhibited aneuploidy as well as centrosome amplification (Xie et al., 2007). Other known metal carcinogens such as arsenic, cadmium, cobalt, and nickel also induce numerical $\mathrm{CIN}$, indicating that aneuploidy is an early event in metal carcinogenesis (S. S. Wise \& Wise, 2010). Metal-induced centrosome amplification is understudied, but has been observed after arsenic and chromium treatments (S. S. Wise \& Wise, 2010). Thus, aneuploidy is a key event in metal carcinogenesis and centrosome amplification is a good candidate mechanism for its induction.

\section{Centrosomes in Carcinogenesis}

The centrosome is the microtubule organizing center of the cell. It functions to nucleate microtubules and plays roles in cell processes such as 
ciliogenesis, cell motility, cell signaling, Golgi organization and mitotic spindle formation. The mature centrosome is a membrane-free organelle composed of two centrioles surrounded by an amorphous congregation of proteins known as the pericentriolar material. The centrioles are cylindrical tubes formed of nine triplet stacks of microtubules. They are about 0.5 um in length and 0.2 um wide (Agircan, Schiebel, \& Mardin, 2014). The pericentriolar material contains multiple associated proteins, including gamma-tubulin which acts as the seed to nucleate microtubules. While the pericentriolar material imparts functionality to the centrosomes, the centrioles determine the replication status of the centrosome (Agircan et al., 2014).

The focus on centrosomes in cancer lies in their powerful influence over chromosome segregation. In culture, multipolar cells featuring more than two centrosomes are observed to segregate chromosomes asymmetrically or into more than two daughter cells. For the most part, severe asymmetry and multicellular cytokinesis is fatal to the daughter cells. However, centrosome amplification can be tolerated by clustering or inactivating supernumerary centrosomes (Brinkley, 2001). The cell may enter prophase with a multipolar phenotype when merotelic attachments can occur and cause asymmetrical chromosome segregation, even if centrosomes cluster to form bipolarity. Also, clustered centrosomes can block one another to interfere with proper microtubule-kinetochore attachment.

Centrosome amplification can occur by various avenues. Failure of cytokinesis results in cells that have a $4 \mathrm{~N}$ complement of DNA and inherit two 
centrosomes instead of one per cell. These centrosomes can then duplicate during S phase, giving the cell four mature centrosomes (Fukasawa, 2005). De novo centrosome amplification occurs when centriolar synthesis proteins are overexpressed and form centrosomes independently of mother centrioles (Godinho \& Pellman, 2014; Tsou \& Stearns, 2006a). Another scenario involves fragmentation of the pericentriolar material which then is able to function as an acentriolar centrosome (Fukasawa, 2005). $\mathrm{Cr}(\mathrm{VI})$ exposed cells do not show a large number of acentriolar centrosomes and amplification occurs in cells with diploid DNA content, indicating that cytokinesis failure is not a prominent source of centrosome amplification (Holmes et al., 2010). The most likely mechanism for $\mathrm{Cr}(\mathrm{VI})$-induced centrosome amplification is premature reduplication during interphase. Evidence points to premature disengagement and loss of reduplication blocks as key steps in amplification (Martino et al., 2015).

Normally, in late mitosis or early $\mathrm{G} 1$, the centriole pair disengages. Disengagement is the licensing step for duplication (Tsou \& Stearns, 2006a, 2006b). Engagement is posited to block recruitment of centriolar synthesis proteins, including Plk4, SAS6, Cep135, and STIL, required to form the daughter centriole cartwheel on the side of the mother centriole (Conduit, Wainman, \& Raff, 2015; Nigg \& Stearns, 2011; Wang, Jiang, \& Zhang, 2014). Thus, the timing of centriole disengagement is important for limiting the centrosomes to one round of duplication and aberrant disengagement could permit additional centrosome formation. Centrosome overduplication along with centriole disengagement has been seen to occur during extended G2 arrest in the presence of DNA damaging 
agents (Dodson et al., 2004; Douthwright \& Sluder, 2014; Inanc, Dodson, \& Morrison, 2010; Karki, Keyhaninejad, \& Shuster, 2017). Martino, et al., reported significant premature centriole disengagement induction after exposure of human lung cells to lead chromate (Martino et al., 2015). Increase in centriole disengagement followed a similar pattern over time and treatment concentrations as centrosome amplification in those cells, supporting the theory of centriole disengagement as a key process in $\mathrm{Cr}(\mathrm{VI})$-induced centrosome amplification (Martino et al., 2015).

Descriptions of normal centrosome duplication can be found in several published works (Agircan et al., 2014; Darling, Fielding, Sabat-Pospiech, Prior, \& Coulson, 2017; Godinho \& Pellman, 2014; Wang et al., 2014) and are summarized here. Daughter centriole assembly takes place in S phase. The daughter centriole assembles on the outer wall of the mother centriole, which serves as a platform for procentriole formation. The daughter centriole continues to elongate throughout $\mathrm{S}$ and $\mathrm{G} 2$ phase. Pericentriolar material increasingly accumulates around the centrosome, and reaches its maximum density, or maturation, at mitosis when it facilitates the nucleation of the spindle fibers. During synthesis in S and G2 phases, the two duplicating centrosomes remain in close proximity to one another by a flexible protein tether. At the G2/M transition, this linkage severs and the centrosomes move apart to opposite poles of the cell. In M phase, the centrosomes become situated at opposing sides of the nucleus allowing for microtubules to access kinetochores and efficiently and faithfully segregate the chromosomes. 
Premature centrosome separation has been observed in human lung cells exposed to particulate hexavalent chromate (Martino et al., 2015). The mechanism of separation is unknown, but it is known that timing of centrosome separation is dependent on cell type and growth conditions and that many cancer cells have higher instances of separated centrosomes (Agircan et al., 2014). When centrosomes are separated before nuclear envelope breakdown, microtubule assembly is quicker and fewer chromosome segregation errors occur (Kaseda, McAinsh, \& Cross, 2012). Early centrosome separation may be advantageous to cancer cells in tolerating centrosome amplification, but this remains to be seen. The coincidence of centrosome separation with centrosome amplification and premature centriole splitting (Martino et al., 2015) suggests that the centrosome tether may protect against centriole disengagement.

\section{Whales as Model Species for Environmental Toxicology}

Hexavalent chromium is a global environmental contaminant present in air, soil and water. Naturally occurring chromium is stable as $\mathrm{Cr}(\mathrm{III})$, which is one of the top 10 most abundant minerals in Earth's crust (Jacobs \& Testa, 2005) and is found in chromite ores such as ferrochromite (Tchounwou, Yedjou, Patlolla, \& Sutton, 2012). Hexavalent chromium can form naturally from oxidation reactions with $\mathrm{Cr}$ (III) (Jacobs \& Testa, 2005), but $\mathrm{Cr}(\mathrm{VI})$ in the environment largely arises from industrial activities. In 1992, Geisler and Schmidt (Geisler, 1992) provided an overview of marine chromium. They reported the thermodynamically stable valence state and the dominant species of chromium in sea water is $\mathrm{Cr}(\mathrm{VI})$. 
Erosion and industrial runoff contribute to chromium input into the ocean, but another large source is deposition from the air, which indicates that both marine waters and atmosphere are contaminated with $\mathrm{Cr}(\mathrm{VI})$ (Geisler, 1992; Jacobs \& Testa, 2005; Tchounwou et al., 2012). The range of chromium levels in sea water have been reported as 5 to $800 \mu \mathrm{g} / \mathrm{L}$ (Jacobs \& Testa, 2005) and 2 to $5 \mathrm{nmol} / \mathrm{kg}$ (Geisler, 1992). Environmental reduction of $\mathrm{Cr}(\mathrm{VI})$ to $\mathrm{Cr}(\mathrm{III})$ can occur in acid conditions, for example in anoxic marine zones with hydrogen sulfide present (Geisler, 1992).

Whales are of particular interest in environmental toxicology because they are the closest marine relative to humans. Whales have long life spans, breathe air, and are potentially exposed to $\mathrm{Cr}(\mathrm{VI})$ by skin, ingestion, and inhalation. Chromium concentrates in whale skin and levels vary among geographically diverse populations. Wise, et al., (2009) analyzed sperm whale skin biopsies from 361 individuals across 16 ocean regions (J. P. Wise, Sr. et al., 2009). Chromium levels ranged from 0.9 to $122.6 \mu \mathrm{g} / \mathrm{g}$ of tissue, with a global mean of $8.8 \pm 0.9 \mu \mathrm{g} / \mathrm{g}$, which is 28 -fold higher than the mean Cr levels in human skin without occupational exposure. Regional means ranged from $3.3 \pm 0.4 \mu \mathrm{g} / \mathrm{g}$ to $44.3 \pm 4.4 \mu \mathrm{g} / \mathrm{g}$. Fin whale skin biopsies from the Gulf of Maine had mean $\mathrm{Cr}$ level of $10.07 \mu \mathrm{g} / \mathrm{g}$ tissue (C. F. Wise, Wise, Thompson, Perkins, \& Wise, 2015).

Sperm whales have the distinction of being deep divers. Unlike baleen whales that feed mostly at surface, sperm whales hunt at depths of 1000 meters and have been recorded at depths over 2000 meters (Watkins, et al., 2002; Zimmer, et al., 2003). They typically remain submerged for 45 minutes, and can 
hold their breath for longer than 90 minutes (Watkins, et al., 2002; Watwood, et al., 2006). Thus, sperm whales experience vast ranges of hydrostatic pressure, which likely shaped the evolution of cell strategies to cope with the effects of high and variable pressure. Hydrostatic pressure changes induce oxidative stress and DNA damage (Aersten, et al., 2005; Dixon, et al., 2004). Increased hydrostatic pressure on lung cancer cells caused increased motility in vitro and enhanced metastasis in vivo (Kao et al., 2017). Cultured epithelial cells under pressure showed greater cell proliferation, suppressed apoptosis, and increased transmembrane ion permeability (Tokuda et al., 2015). Sperm whales are one of the few mammalian species that routinely tolerate extreme pressure changes (Tyak, et al., 2006). Additionally, reports of chromium speciation in oceans has found that $\mathrm{Cr}(\mathrm{VI})$ concentrations increase in deep waters (Geisler, 1992) and thermal vents emit heavy metals, making the deep ocean an interesting place to study metal toxicity.

The bowhead whale is one of the largest whale species and with lifespans in excess of 200 years it is suspected to be the longest living mammal (Keane et al., 2015). However, the incidence of age-related diseases such as cancer is remarkably low in whales as compared to humans (Caulin \& Maley, 2011). Also, the risk of cancer should theoretically scale up in large animals with over 1,000 times more cells than humans. However, in what is known as Peto's paradox, this theoretical relationship between size, age, and cancer incidence does not manifest across species, and is evidence that whales have cancer-suppressing adaptations (Caulin \& Maley, 2011). Bowhead whale genome sequencing and 
comparative analysis shows gene duplication and loss in genes associated with DNA repair, cell cycle regulation, cancer, and aging (Keane et al., 2015). Greater understanding of how whales maintain genomic stability can advance prevention and treatment of human cancers.

Interestingly, cell culture studies have shown that particulate $\mathrm{Cr}(\mathrm{VI})$ is less genotoxic to whale cells than human cells (Browning, Wise, \& Wise, 2017; Li Chen et al., 2012; Li Chen et al., 2009). Fewer instances of structural chromosome damage occurred to North Atlantic right whale lung cells versus human lung fibroblasts exposed to lead chromate (Li Chen et al., 2009). Lead chromate produced 3- to 5-fold fewer damaged metaphases in sperm whale skin cells compared to human skin cells (Li Chen et al., 2012). Thus, it appears that whales have protective mechanisms against $\mathrm{Cr}(\mathrm{VI})$-induced structural chromosome damage. This thesis investigates cytotoxicity and numerical chromosome instability in whale cells after particulate $\mathrm{Cr}(\mathrm{VI})$ exposure. Furthermore, centrosome amplification is assessed after $\mathrm{Cr}(\mathrm{VI})$ exposure, as it is the dominant candidate mechanism for causing numerical CIN. 


\section{MATERIALS AND METHODS}

\section{Chemicals and Reagents}

DMEM and Ham's F-12 (DMEM/F-12) 50:50 media, glutagro 200 mM Lalanyl-L-glutamine supplement, sodium pyruvate, and Dulbecco's phosphatebuffered saline (DPBS) were purchased from Corning, Inc. (Manassas, VA). Cosmic calf serum and penicillin/streptomycin was purchased from HyClone (Logan, UT). Tissue culture flasks, dishes and plasticware were purchased from Corning, Inc. (Corning, NY). Glass chamber slides were purchased from Thermo Fischer Scientific (Rochester, NY). Super Up Rite slides were purchased from Richard Allen Scientific/Thermo Fischer Scientific (Kalamazoo, MI). FNC Coating Mix $^{\circledR}$ (fibronectin, collagen, albumin mix) was purchased from Athena Environmental Sciences, Inc. (Baltimore, MD). Methanol, sodium dodecyl sulfate (SDS), potassium chloride, nitric acid and micro cover glass were purchased from VWR International (Radnor, PA). Acetic acid was purchased from Avantor (Center Valley, PA). Gurr's buffer and $0.25 \%$ tryspin-ethylenediaminetetraacetic acid (EDTA) were purchased from Life Technologies Corporation (Grand Island, NY). Giemsa stain was purchased from Ricca Chemical Company (Arlington, TX). Ethylene glycol tetraacetic acid (EGTA), fish skin gelatin, glycerol and demecolcine were purchased from Sigma-Aldrich, Inc. (St. Louis, MO). Normal 
goat serum was purchased from Abcam (Eugene, OR). Piperazine-N,N'-bis(2ethanesulfonic acid) (PIPES) was purchased from Alfa Aesar (Ward Hill, MA). Magnesium sulfate was purchased from J.T. Baker (Phillipsburg, NJ). Bovine serum albumin was purchased from EMD Millipore Corporation (Billerica, MA). Sodium azide was purchased from Amresco, Inc. (Solon, OH). Anti-centrin monoclonal antibody was purchased from EMD Millipore Corporation (Temecula, CA). Anti-CNAP1 (CEP250) rabbit polyclonal antibody was purchased from Proteintech (Rosemont, IL). Prolong Diamond Antifade Reagent with DAPI and Alexa Fluor secondary antibodies were purchased from Invitrogen (Eugene, OR).

\section{Cell Culture}

SPW457sk is a primary skin fibroblast cell line derived from a female sperm whale. Skin biopsy was obtained from a free ranging, healthy adult in the Gulf of Mexico. BHW200Lu is a primary bowhead whale lung fibroblast cell line derived from a male whale obtained during a subsistence hunt in Barrow, AK. Cytotoxicity was performed in BHW24Lu cells, from another subsistence-hunted bowhead whale. Fibroblast cell lines provide relevant cell models due to observations that chromium deposits in the bronchial stroma of chromate workers, but not in the epithelium (Kondo et al., 2003). Human fibroblast cells are typically employed in toxicological assays concerning aneuploidy given that epithelial cell lines already demonstrate aneuploidy. Furthermore, attempts to create whale epithelial cell lines have not been successful. 


\section{Preparation of Zinc Chromate and Cell Treatments}

For all experiments, cells were seeded and allowed 72 hours to enter logarithmic growth phase. Zinc chromate was suspended in sterile water and stirred overnight at $4^{\circ} \mathrm{C}$. Before treatment, media were changed and zinc chromate suspension was added at a concentration of $0,0.1,0.15,0.2,0.3$, or $0.4 \mathrm{\mu g} / \mathrm{cm}^{2}$, unless otherwise specified. Treatment durations were 24 and 120 hours. Cells in treatment were maintained at $33^{\circ} \mathrm{C}$ and $5 \% \mathrm{CO}_{2}$ in a humidified incubator.

\section{Clonogenic Survival Assay}

Cells were seeded on 6-well plates and treated as described above. At the end of the treatment period, media were removed and cells were rinsed with DPBS and released from the plate with $0.25 \%$ trypsin-EDTA. From each treatment condition, 2000 cells were seeded onto each of four $100 \mathrm{~mm}$ dishes. Cells were maintained in culture, without any further treatment, and media were changed every 5 days until colonies formed. Colonies were stained with crystal violet. Colonies were counted in each dish and averaged across all dishes for each treatment. Average colony growth on treatment groups are reported relative to the control group. Three experiments were performed.

\section{Aneuploidy Analysis}

Cells were seeded into $100 \mathrm{~mm}$ dishes and allowed 72 hours to enter logarithmic growth phase. Cells were treated with zinc chromate as above. Five 
hours before harvesting, $0.1 \mu \mathrm{g} / \mathrm{mL}$ demecolcine was added to each dish to arrest cells in metaphase. After 24 hours or 120 hours of exposure, media and treatment were rinsed from the dishes and cells were released from the plate with $0.25 \%$ trypsin-EDTA. Cells were washed in PBS, treated with hypotonic $0.075 \mathrm{M}$ potassium chloride for 17 minutes, and fixed in Carnoy's fixative for 20 minutes. Fixative was changed twice before preparing slides. Fixed cells were then dropped onto wet glass slides and dried at $30^{\circ} \mathrm{C}, 30 \%$ humidity. Slides were stained with Giemsa and glass cover slips were applied. Chromosomes were counted in at least 100 metaphases per concentration. Normal diploid sperm whale and bowhead whale cells contain 42 chromosomes. Any metaphases with greater or fewer than 42 chromosomes were counted as aneuploid. Three experiments were analyzed.

\section{Spindle Assembly Checkpoint Bypass Assay}

Cells were treated, prepared, and solid-stained as in the aneuploidy assay. Mitotic damage including centromere spreading, premature centromere division, and premature anaphase was recorded. A minimum of 100 diploid metaphases per concentration were analyzed and mitotic damage was recorded in all metaphases encountered during analysis. Three experiments were analyzed.

\section{Centrosome Immunofluorescence Assay}

Cells were seeded on glass, FNC-coated chamber slides. Cells were allowed 72 hours to enter logarithmic growth before treatment with zinc chromate. 
Treatment concentrations were $0,0.2,0.3$, and $0.4 \mu \mathrm{g} / \mathrm{cm}^{2}$ zinc chromate. After 24 hours or 120 hours exposure, media were aspirated and cells were washed twice with microtubule stabilizing buffer ( 3 mM EGTA, 50 mM PIPES, 1 mM $\mathrm{MgSO}_{4}, 25 \mathrm{mM} \mathrm{KCl}$ ), fixed with $-20^{\circ} \mathrm{C}$ methanol for 10 minutes and allowed to air dry completely. Cells were rehydrated for 3 minutes in $0.05 \%$ Triton X-100, followed by 30 minutes of blocking. Cells were incubated with anti- $\gamma$-tubulin antibody and either CNAP1 or $\alpha$-tubulin-FITC antibody for 1 hour each, washing in PBS 3 times between each incubation. Cells were incubated with isotypespecific Alexa Fluor 555 and Alexa Fluor 633 to stain CNAP1 and $\gamma$-tubulin, or Dylight 549 to stain $\gamma$-tubulin with the FITC-conjugated antibody. Cells were washed and aged overnight before mounting coverslips with Prolong Diamond Antifade Mountant with DAPI. Slides were analyzed on fluorescent microscope. Centrosome number was counted in 100 interphase and 50 mitotic cells per treatment. Two experiments were analyzed.

\section{Chromium Uptake Assay}

Cells were seeded into $60 \mathrm{~mm}$ dishes and treated as described above. Harvests were performed at the time of treatment and after 24 hours and 120 hours of exposure. Extracellular chromium was analyzed from culture media passed through a $0.2 \mu \mathrm{m}$ filter. To obtain Intracellular samples, plates were rinsed with DPBS and cells were released using $0.25 \%$ trypsin-EDTA. Cell counts and cell diameter were recorded. Cells were washed twice in DPBS and suspended in $1 \mathrm{ml} 0.075 \mathrm{M}$ hypotonic potassium chloride for 5 minutes. One 
milliliter $2 \%$ sodium dodecyl sulfate was added for 15 minutes to rupture the cell membrane and the suspension was sheared through an 18G needle 7 times. Lysate was filtered through a $0.2 \mu \mathrm{m}$ filter. All samples were diluted in $2 \%$ nitric acid. Extracellular and intracellular chromium was analyzed by atomic absorption spectroscopy. Three experiments were analyzed.

\section{Statistical Analysis}

Values are expressed as the mean \pm SEM (standard error of the mean).

Clonogenic survival, aneuploidy, spindle assembly checkpoint bypass, and chromium uptake were analyzed by single factor ANOVA $(\alpha=0.05)$ to determine the significance of zinc chromate treatments within each time point. Two-tailed Student's t-tests were performed for all assays to determine differences between each chromate concentration and the untreated control for each time point. 


\section{RESULTS}

\section{Particulate Hexavalent Chromium is Cytotoxic to Whale Cells.}

After 24 hours of zinc chromate treatment at $0.1,0.15,0.2,0.3$, and 0.4 $\mu \mathrm{g} / \mathrm{cm}^{2}$, sperm whale skin fibroblasts produced colonies at $89.3 \%, 80.8 \%, 70.3 \%$, $66.3 \%$, and $51.1 \%$ relative to untreated cells (Figure 1). After 120 hours of treatment at the same concentrations, relative survival was $85.2 \%, 80.9 \%$, $64.7 \%, 47.6 \%$, and $19.6 \%$ respectively. Survival was statistically less than control at $0.2,0.3$ and $0.4 \mu \mathrm{g} / \mathrm{cm}^{2}$ for both time points. After 24 hours of zinc chromate treatment at $0.1,0.15,0.2,0.3$, and $0.4 \mu \mathrm{g} / \mathrm{cm}^{2}$, bowhead whale lung fibroblasts produced colonies at $96.7 \%, 92.5 \%, 90.3 \%, 86.8 \%$ and $79.3 \%$ relative to untreated cells (Figure 2), with the highest concentration producing significantly different results compared to control. Relative survival after 120 hours of exposure was similar to 24 hour exposures at $94.1 \%, 90.2 \%, 80.6 \%, 79.3 \%$, and $79.5 \%$. The difference compared to control was significant for $0.2,0.3$ and 0.4 $\mu \mathrm{g} / \mathrm{cm}^{2}$ zinc chromate treatments. Sperm whale and bowhead whales show different responses to prolonged $\mathrm{Cr}(\mathrm{VI})$ exposure. While survival after 120 hours decreased in sperm whale cells, in bowhead whale cells survival rates were not significantly less than after 24 hour exposures. 


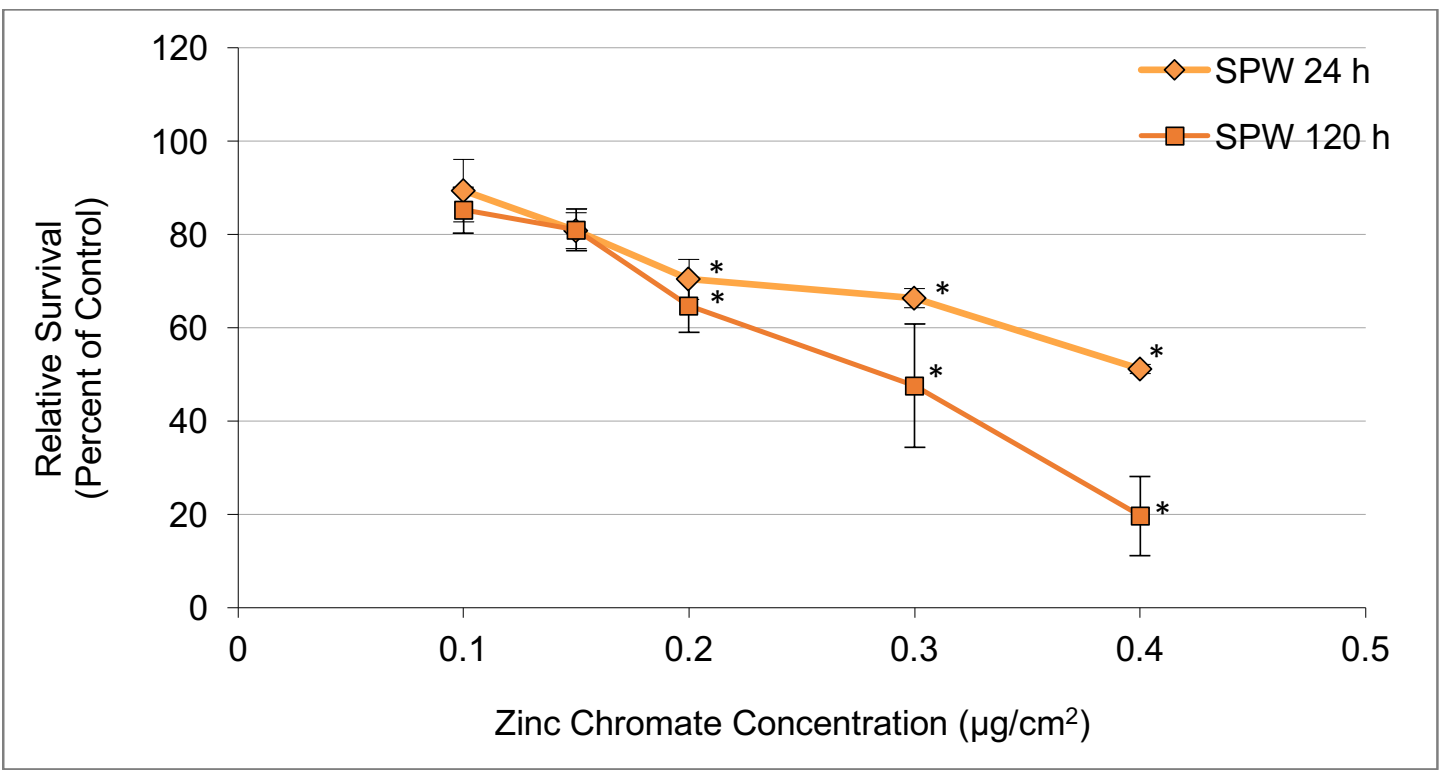

Figure 1: Colony survival relative to control. Mean $\pm \mathrm{SEM}, \mathrm{N}=3$.

*Significantly different from control (Student t-test, $p<0.05$ )

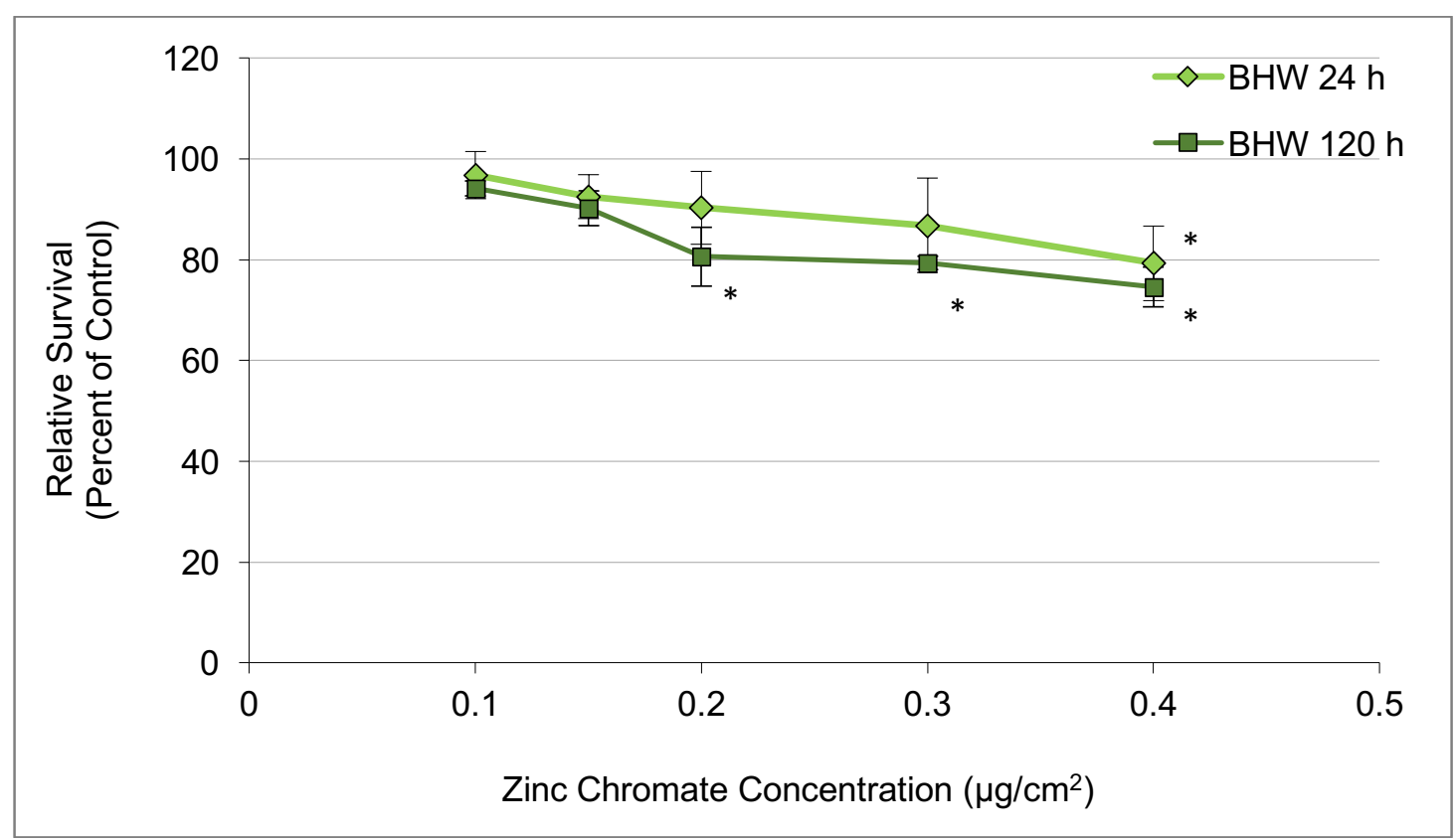

Figure 2: Colony survival relative to control. Mean $\pm \mathrm{SEM}, \mathrm{N}=3$.

${ }^{*}$ Significantly different from control (Student t-test, $p<0.05$ ) 


\section{Cr(VI) Does Not Induce Spindle Assembly Checkpoint Bypass in Whale Cells}

Spindle assembly checkpoint (SAC) is a mechanism that prevents progression from metaphase to anaphase until all kinetochores are properly attached to spindle fibers. Particulate chromate has been shown to cause SAC bypass in human lung fibroblasts, observed as centromere spreading, premature centromere division, and premature anaphase (Holmes et al., 2010; S. S. Wise, Holmes, Xie, Thompson, \& Wise, 2006). Definitions of these phenomena are described in Wise, et al. (2006) and followed here (S. S. Wise et al., 2006). Centromere spreading entails separation of the chromatids at the centromere only and not the entire length of the chromosome. Premature centromere division is defined as at least one chromosome fully dissociated from its sister chromatid, while at least one other chromosome was attached. Premature anaphase is defined as all chromosomes being completely separated. The SAC is a protective mechanism against aneuploidy. SAC bypass allows cell division to occur in conditions of improper kinetochore-microtubule attachments, resulting in lagging chromosomes at anaphase and asymmetrical chromosome segregation.

Strikingly, sperm whale skin fibroblasts show resistance to particulate chromate-induced SAC bypass (Figure 3). All treatments showed zero increase in centromere spreading after 24 and 120 hours. After 24 and 120 hours, premature centromere division and premature anaphase occurred in 0.3 to $1.0 \%$ of metaphases in a non-dose dependent fashion. 
Bowhead whale lung fibroblasts also show resistance to SAC bypass

(Figure 4). No centromere spreading was observed in any treatment concentrations after either 24 or 120 hours. Premature centromere division occurred in $0.5 \%$ of cells after both 24 and $120 \mathrm{~h}$ at $0.4 \mu \mathrm{g} / \mathrm{cm}^{2}$ zinc chromate concentration.

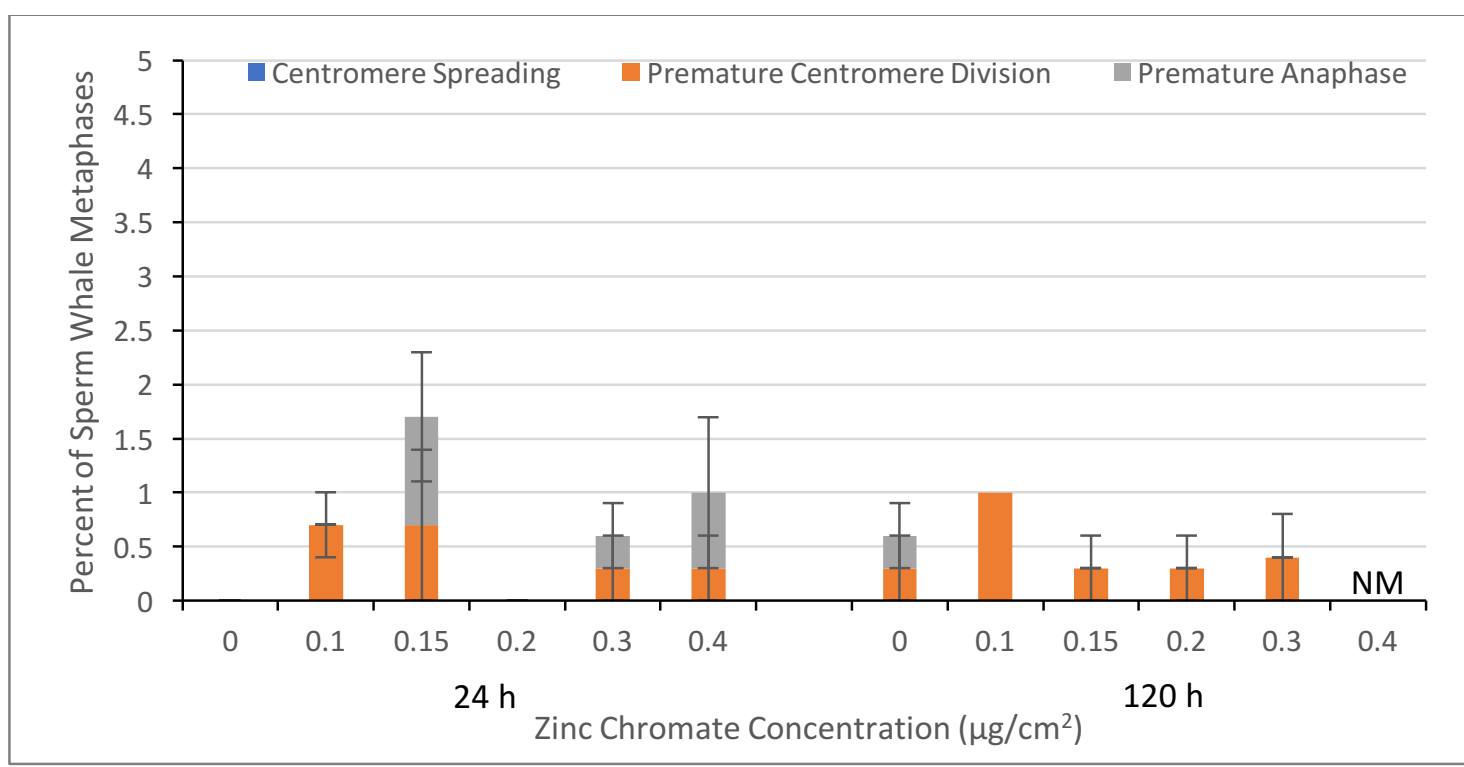

Figure 3: Percent of sperm whale skin fibroblast metaphases with centromere spreading, premature centromere division, and premature anaphase in stacked columns. $\mathrm{NM}=$ not enough metaphases. Mean $\pm \mathrm{SEM}, \mathrm{N}=3$. No treatment significantly different from control (Student t-test, $p<0.05$ ). 


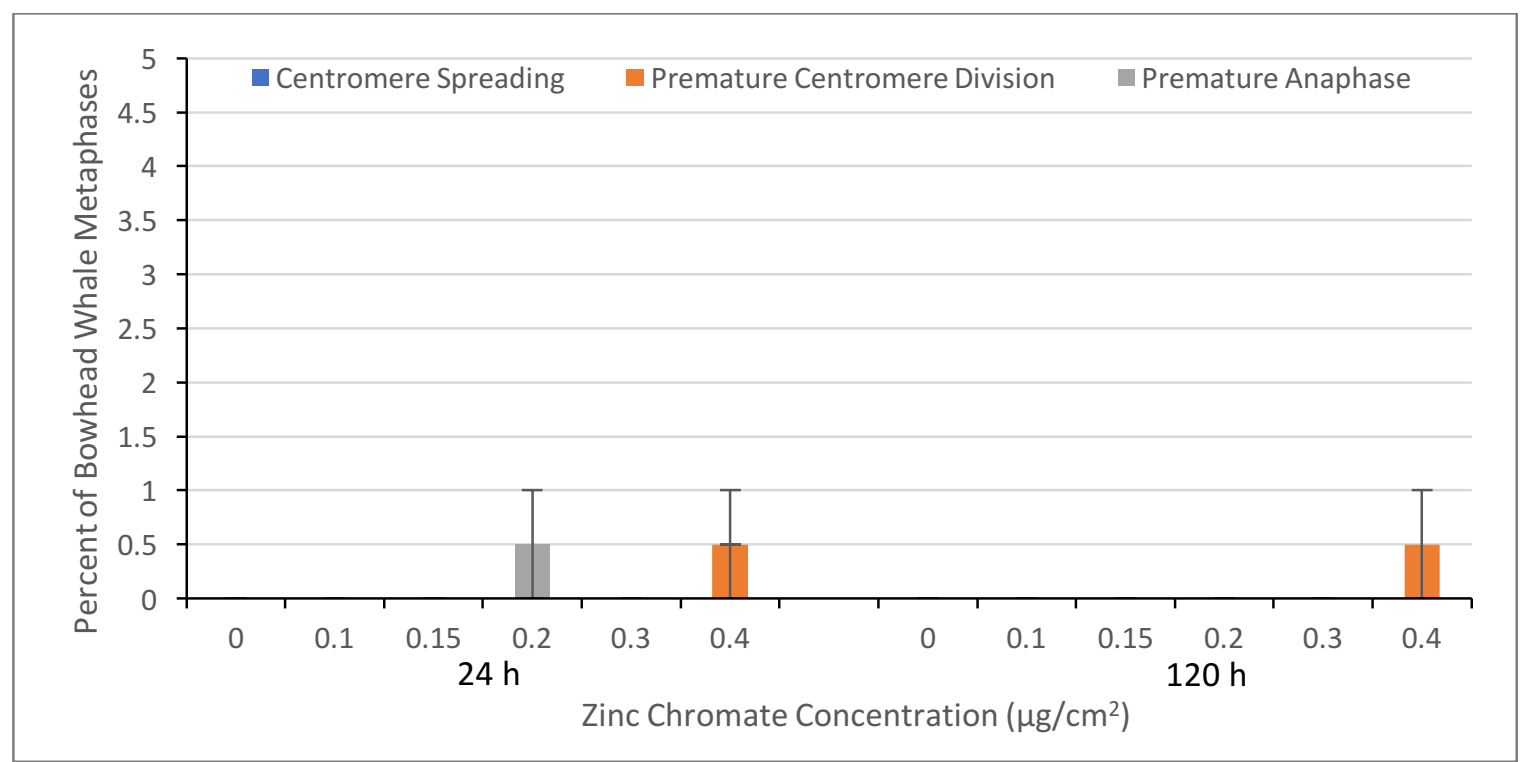

Figure 4: Percent of bowhead whale lung fibroblast metaphases with centromere spreading, premature centromere division, and premature anaphase in stacked columns. Mean $\pm \mathrm{SEM}, \mathrm{N}=3$. No treatment significantly different from control (Student t-test, $p<0.05$ ).

\section{Whale Cells Are Resistant to $\mathrm{Cr}(\mathrm{VI})$-Induced Aneuploidy}

Aneuploidy is defined as the loss or gain of entire chromosomes. We analyzed aneuploidy by metaphase analysis, counting chromosomes per metaphase and classifying those with greater or fewer than 42 chromosomes as aneuploid. We scored 100 metaphases with 40-44 chromosomes and any hyperor hypodiploid metaphases encountered during scoring were also added to the aneuploidy analysis. Metaphases were analyzed for aneuploidy after 24 and 120 hours of zinc chromate treatment.

Sperm whale control cells from the 24 hour treatment group showed $13.8 \%$ aneuploidy and $0.1,0.15,0.2,0.3$, and $0.4 \mu \mathrm{g} / \mathrm{cm}^{2}$ treatment resulted in $16.5 \%, 11.5 \%, 11.9 \%, 12.3 \%$, and $15.5 \%$ aneuploidy respectively (Figure 5 ). The 120 hour control had $12.9 \%$ aneuploidy, while the treatments had $10.2 \%, 17.3 \%$, 
$12.0 \%, 18.6 \%$, and $22.6 \%$ respectively. The elevated percentages at the two highest concentrations are in treatments that failed to produce 100 metaphases. The two highest concentrations, 0.3 and $0.4 \mu \mathrm{g} / \mathrm{cm}^{2}$ zinc chromate, were significantly different from the control bowhead whale cells $(p=0.024$ and $p=0.012$ respectively).

For the 24 hour time point, bowhead whale control group showed $20.3 \%$ aneuploidy while $0.1,0.15,0.2,0.3$, and $0.4 \mu \mathrm{g} / \mathrm{cm}^{2}$ treatment resulted in $21.6 \%$, $26.0 \%, 21.0 \%, 21.3 \%$, and $22.5 \%$ aneuploid metaphases (Figure 6). After 120 hours, control cells showed $23.2 \%$ aneuploidy and treatment resulted in $23.3 \%$, $22.0 \%, 30.8 \%, 25.1 \%$, and $29.0 \%$ aneuploidy. None of the treatment results were significantly different from the control bowhead whale cells.

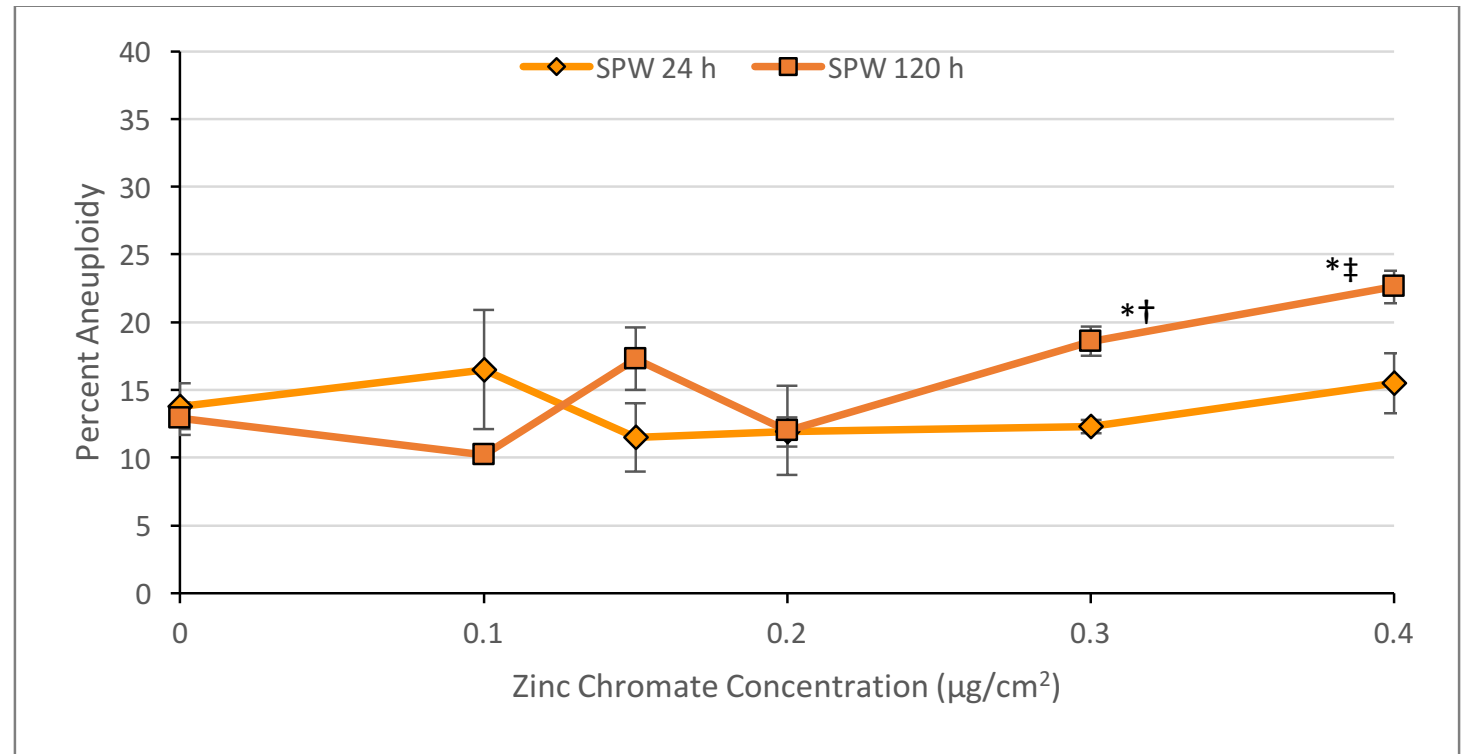

Figure 5: Percent anueploidy encountered among 100 diploid metaphases from sperm whale skin fibroblasts treated with $\mathrm{Cr}(\mathrm{VI})$. $\ddagger F e w e r$ than 50 diploid metaphases present per experiment. $\dagger F$ ewer than 100 diploid metaphases present per experiment. Mean $\pm \mathrm{SEM}, \mathrm{N}=3$. *Significantly different from control (Student t-test, $p<0.05$ ). 


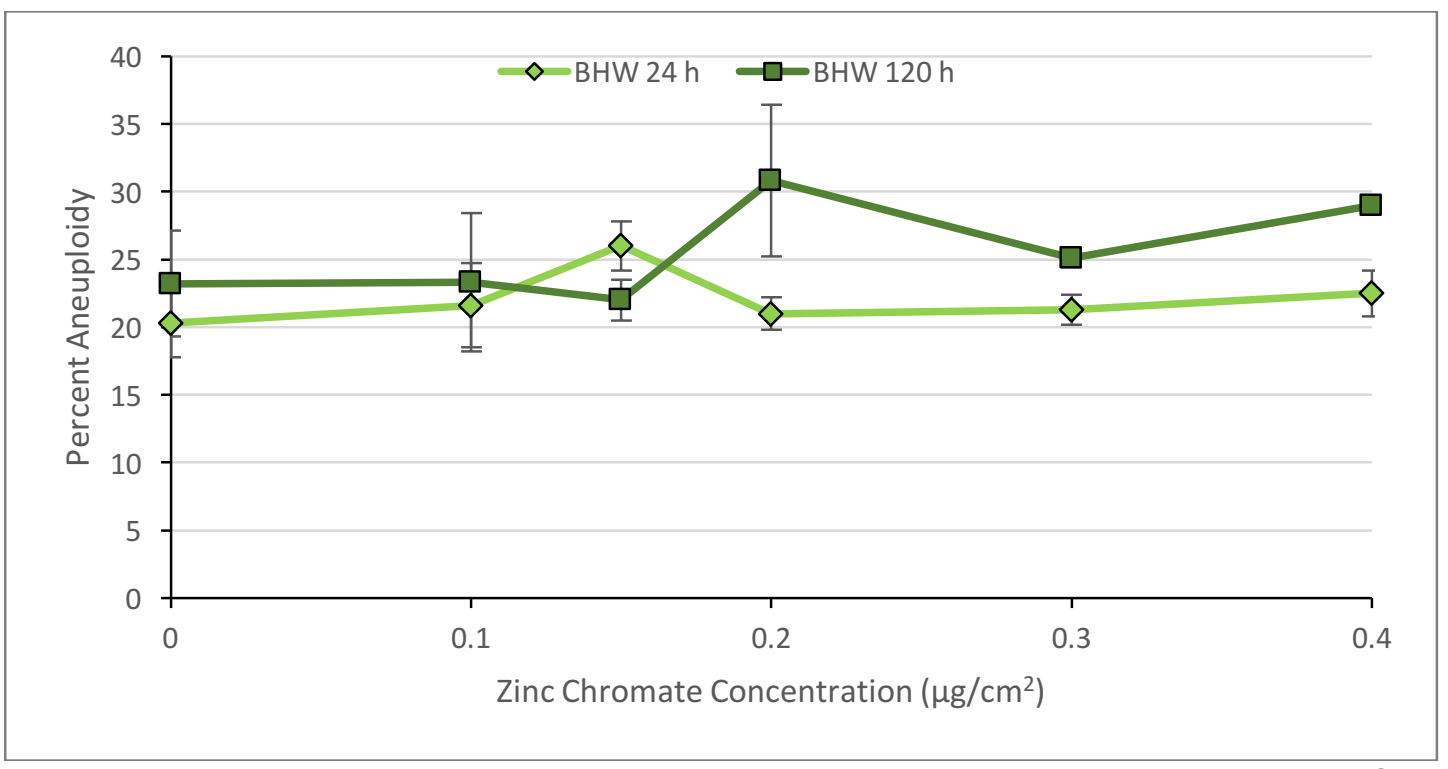

Figure 6: Percent aneuploidy encountered among 100 diploid metaphases from bowhead whale lung fibroblasts treated with $\mathrm{Cr}(\mathrm{VI})$. Mean $\pm \mathrm{SEM}, \mathrm{N}=3$. No treatment different from control (Student t-test, $p<0.05$ ).

\section{Cr(VI) Does Not Induce Centrosome Amplification in Interphase Whale Cells.}

Previous studies show centrosome amplification correlates with aneuploidy(Martino et al., 2015). Further, centrosome amplification has been shown to occur in the prolonged G2 phase induced by DNA damage (Dodson et al., 2004; Holmes et al., 2010; Inanc et al., 2010). We analyzed centrosomes in interphase cells to determine if low rates of aneuploidy were concurrent with low instances of centrosome amplification. Centrosomes were counted in 100 interphase cells per treatment concentration. Sperm whale skin fibroblasts (Figure 7) exposed to $0,0.2,0.3$, and $0.4 \mu \mathrm{g} / \mathrm{cm}^{2}$ zinc chromate for 24 hours had greater than 2 centrosomes in $2.5 \%, 2.0 \%, 3.0 \%$ and $3.0 \%$ of cells respectively. After 120 hours exposure, sperm whale cells showed $4.5 \%, 4.5 \%, 3.5 \%$, and $1.5 \%$ centrosome amplification. Bowhead whale interphase cells (Figure 8) 
exposed to $0,0.2,0.3$, and $0.4 \mu \mathrm{g} / \mathrm{cm}^{2}$ zinc chromate for 24 hours had $1.5 \%$, $3.5 \%, 2.0 \%$, and $2.5 \%$ centrosome amplification. After 120 hours, percent of centrosome amplification was $2.0 \%, 0.5 \%, 6.0 \%$ and $4.0 \%$. No treatments showed significant increase in centrosome amplification in either cell line or exposure time point. Centrosomes were not analyzed in binucleated cells, since the mechanism of interest for this study is centrosome reduplication. Binucleated cells result from cytokinesis failure or cell merging and often contain 4 rather than 2 centrosomes. Most binucleated cells do not reenter mitosis, however those that progressed to mitosis would be included in the mitotic assays we performed.

Preliminary counts show that binucleated cells did not increase with $\mathrm{Cr}(\mathrm{VI})$ treatment.

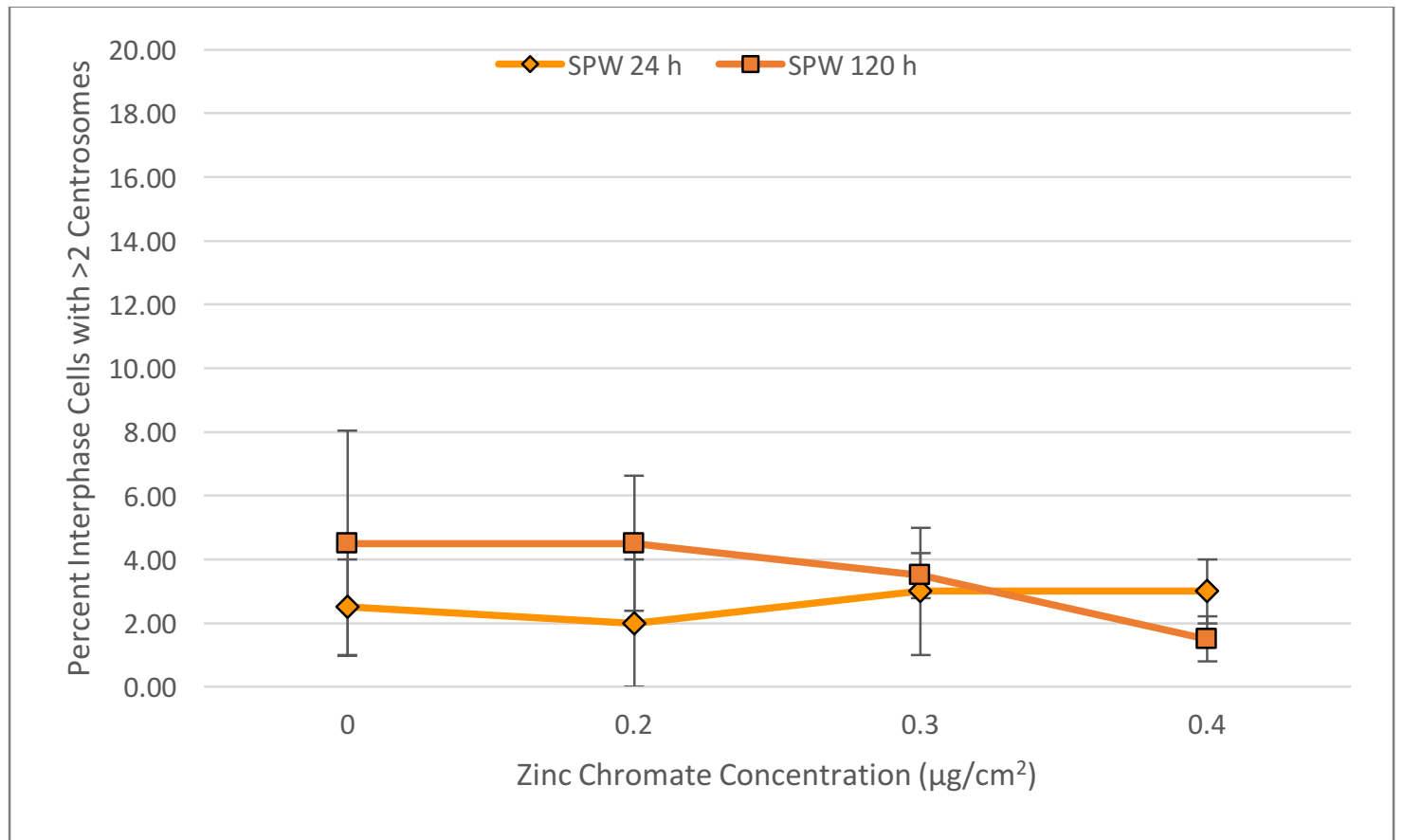

Figure 7: Percent of interphase sperm whale cells with $>2$ centrosomes. 100 cells scored per treatment. Mean $\pm \mathrm{SEM}, \mathrm{N}=2$. No treatment significantly different from control (Student t-test, $p<0.05$ ). 


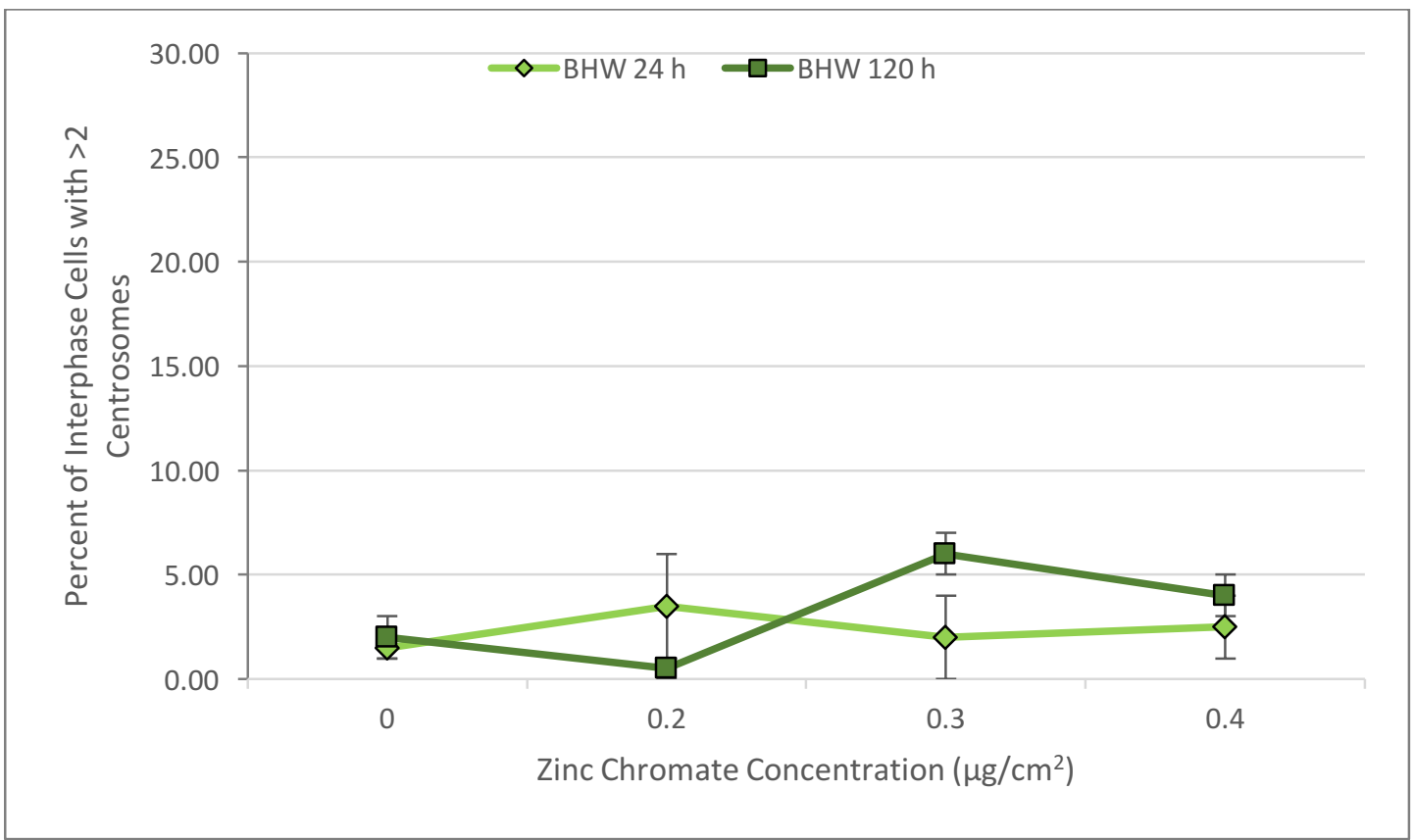

Figure 8: Percent of interphase bowhead whale cells with $>2$ centrosomes. 100 cells scored per treatment. Mean $\pm \mathrm{SEM}, \mathrm{N}=2$. No treatment significantly different from control (Student t-test, $p<0.05$ ).

\section{Cr(VI) Does Not Induce Centrosome Amplification in Mitotic Whale Cells.}

Rare cells with supernumerary centrosomes may progress to mitosis and produce aneuploid daughter cells (Brinkley, 2001; Nigg, Cajanek, \& Arquint, 2014). It is during mitosis that centrosome amplification can cause chromosomal instability, so we also analyzed mitotic cells. Centrosomes were counted in 50 mitotic cells per treatment concentration. After 24 hours, untreated sperm whale cells (Figure 9) contained greater than 2 centrosomes in $7 \%$ of mitotic cells, while $0.2,0.3$, and $0.4 \mu \mathrm{g} / \mathrm{cm}^{2}$ zinc chromate treatment produced $5.2 \%, 1.2 \%$ and $0 \%$ centrosome amplification. Fewer than 50 mitotic cells were found after 24 hour exposures of both 0.3 and $0.4 \mu \mathrm{g} / \mathrm{cm}^{2}$ zinc chromate. After 120 hours, $2 \%$ of untreated mitotic cells had centrosome amplification, and treatment resulted in 
$1 \%, 2 \%$, and $2.9 \%$ centrosome amplification. After 120 hours fewer than 50 mitotic cells were found in the highest concentration of $0.4 \mu \mathrm{g} / \mathrm{cm}^{2}$ zinc chromate.

After 24 hours, an average of $2.19 \%$ untreated mitotic bowhead whale cells (Figure 10) had centrosome amplification. Treatment with $0.2,0.3$, and 0.4 $\mathrm{\mu g} / \mathrm{cm}^{2}$ zinc chromate produced $3.13 \%, 3.17 \%$, and $1.52 \%$ centrosome amplification. After 120 hours, $2 \%$ of untreated mitotic cells had greater than 2 centrosomes, while treated cells showed centrosome amplification in $0 \%, 2 \%$, and $2.13 \%$ of mitotic cells. No treatments showed significant increase in centrosome amplification in either cell line or exposure time point.

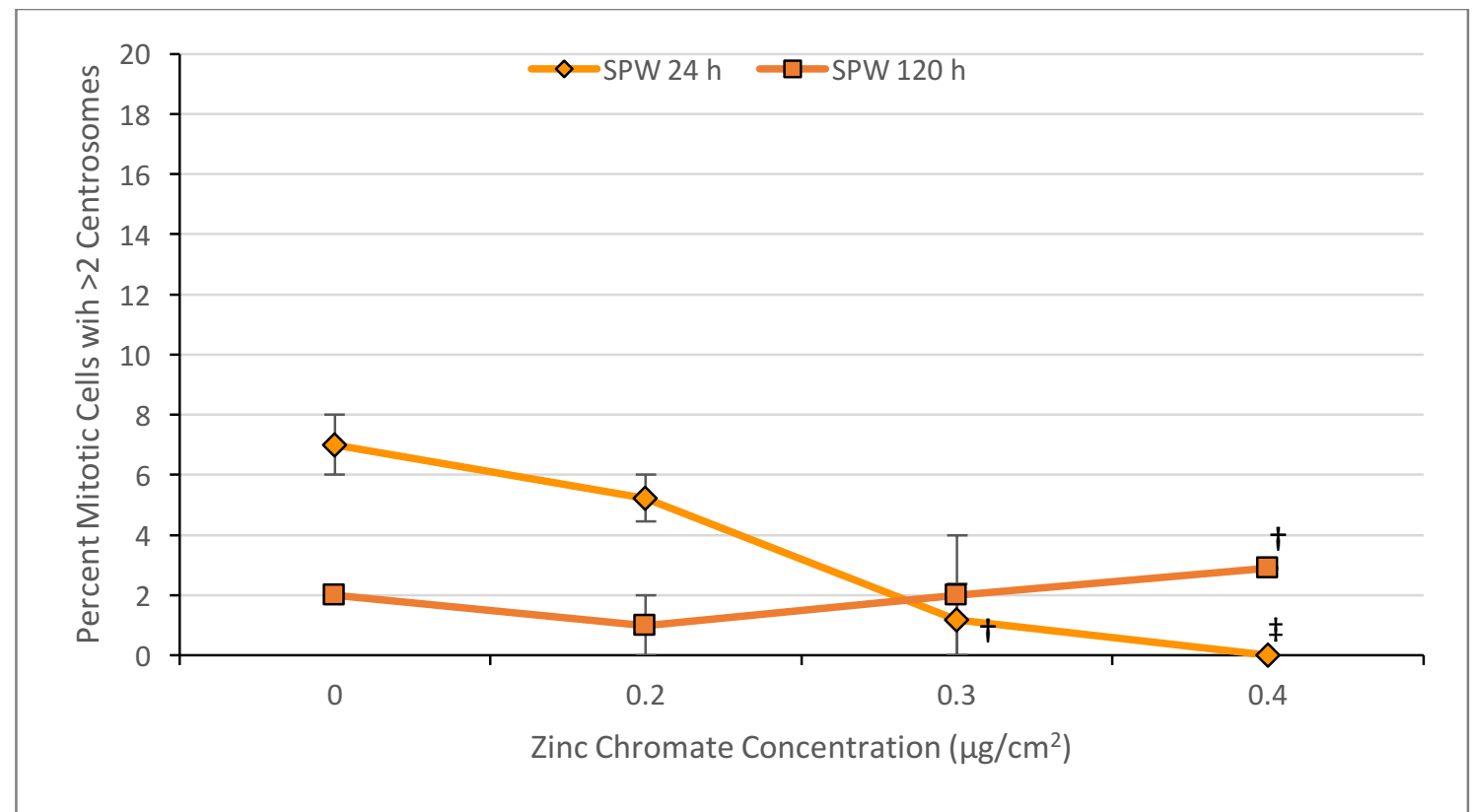

Figure 9: Percent of interphase sperm whale cells with $>2$ centrosomes. 50 cells scored per treatment. $\ddagger F e w e r$ than 25 mitotic cells present per experiment. †Fewer than 45 mitotic cells present per experiment. Mean $\pm \mathrm{SEM}, \mathrm{N}=2$. No treatment significantly different from control (Student t-test, $p<0.05$ ). 


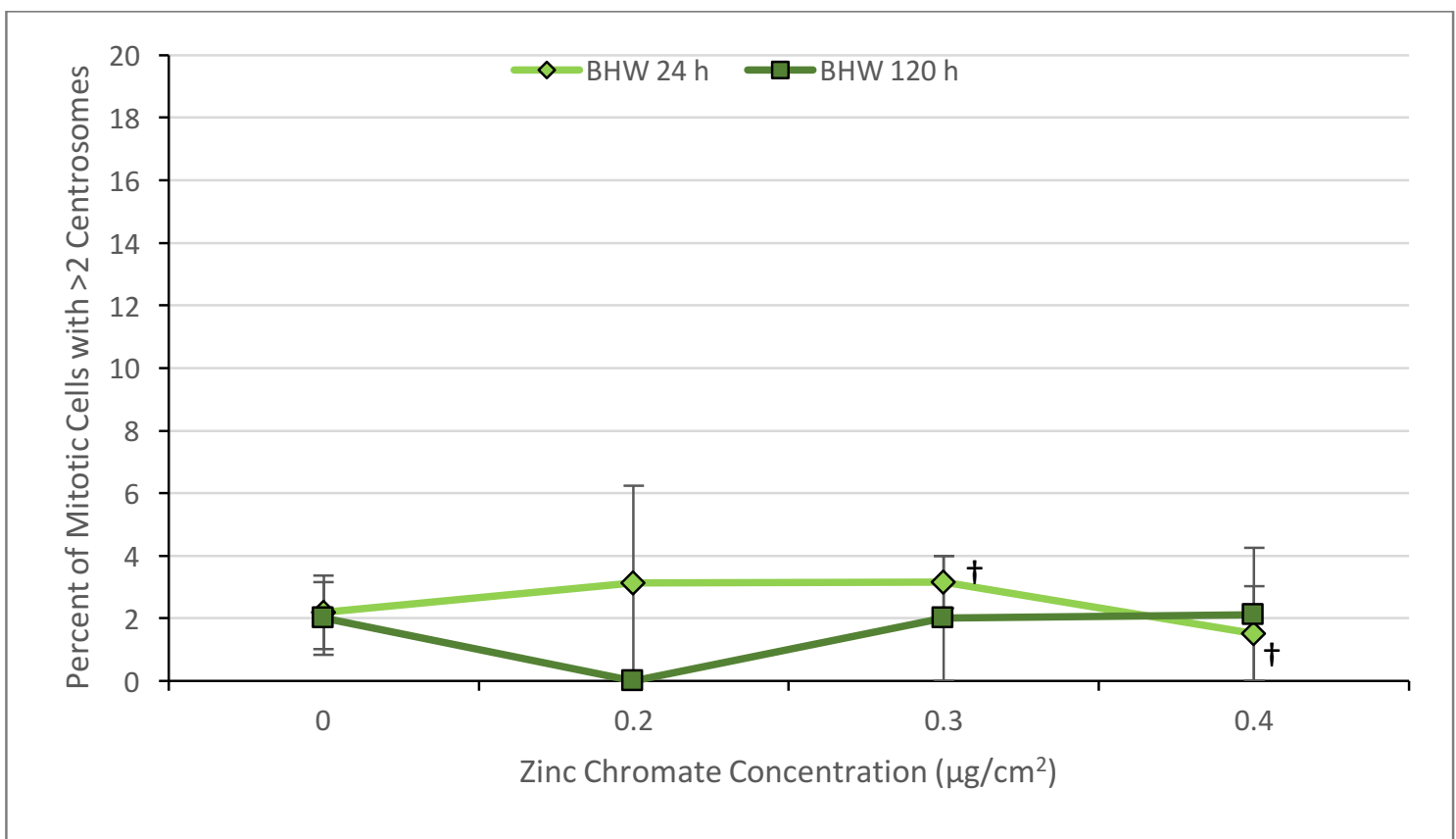

Figure 10: Percent of interphase bowhead whale cells with $>2$ centrosomes. 50 cells scored per treatment. †Fewer than 45 mitotic cells present per experiment. Mean $\pm \mathrm{SEM}, \mathrm{N}=2$. No treatment significantly different from control (Student t-test, $\mathrm{p}<0.05$ ).

\section{Chromium Uptake Differs Between Sperm Whale and Bowhead Whale Cells.}

The difference in cytotoxicity between sperm whale and bowhead whale cells may be caused by differences in $\mathrm{Cr}(\mathrm{VI})$ uptake by the cells. We measured intracellular chromium after treatment at all experimental concentrations for 24 and 120 hours. These data show that intracellular chromium concentration is higher in sperm whale cells than bowhead whale cells (Figure 11) after equal administrations and at both time points. In sperm whale cells (Figure 11), 24 hours of exposure to $0,0.1,0.15,0.2,0.3$, and $0.4 \mu \mathrm{g} / \mathrm{cm}^{2}$ zinc chromate administration lead to average intracellular chromium concentrations of 0,109 , $198,302,427$, and $532 \mu \mathrm{M}$. Exposure of 120 hours at the same administered concentrations resulted in $0,101,195,323,404,862 \mu \mathrm{M}$ chromium. In bowhead 
whale cells (Figure 12), 24 hours of exposure to $0,0.1,0.15,0.2,0.3$, and 0.4 $\mu \mathrm{g} / \mathrm{cm}^{2}$ zinc chromate administration lead to average intracellular chromium concentrations of $0,68,94,89,129$, and $247 \mu \mathrm{M}$. Exposure of 120 hours at the same administered concentrations resulted in $0,78,107,159,278$, and $338 \mu \mathrm{M}$ chromium. Comparing intracellular concentrations between 24 and 120 hour exposures did not reveal significant increases within either cell line.

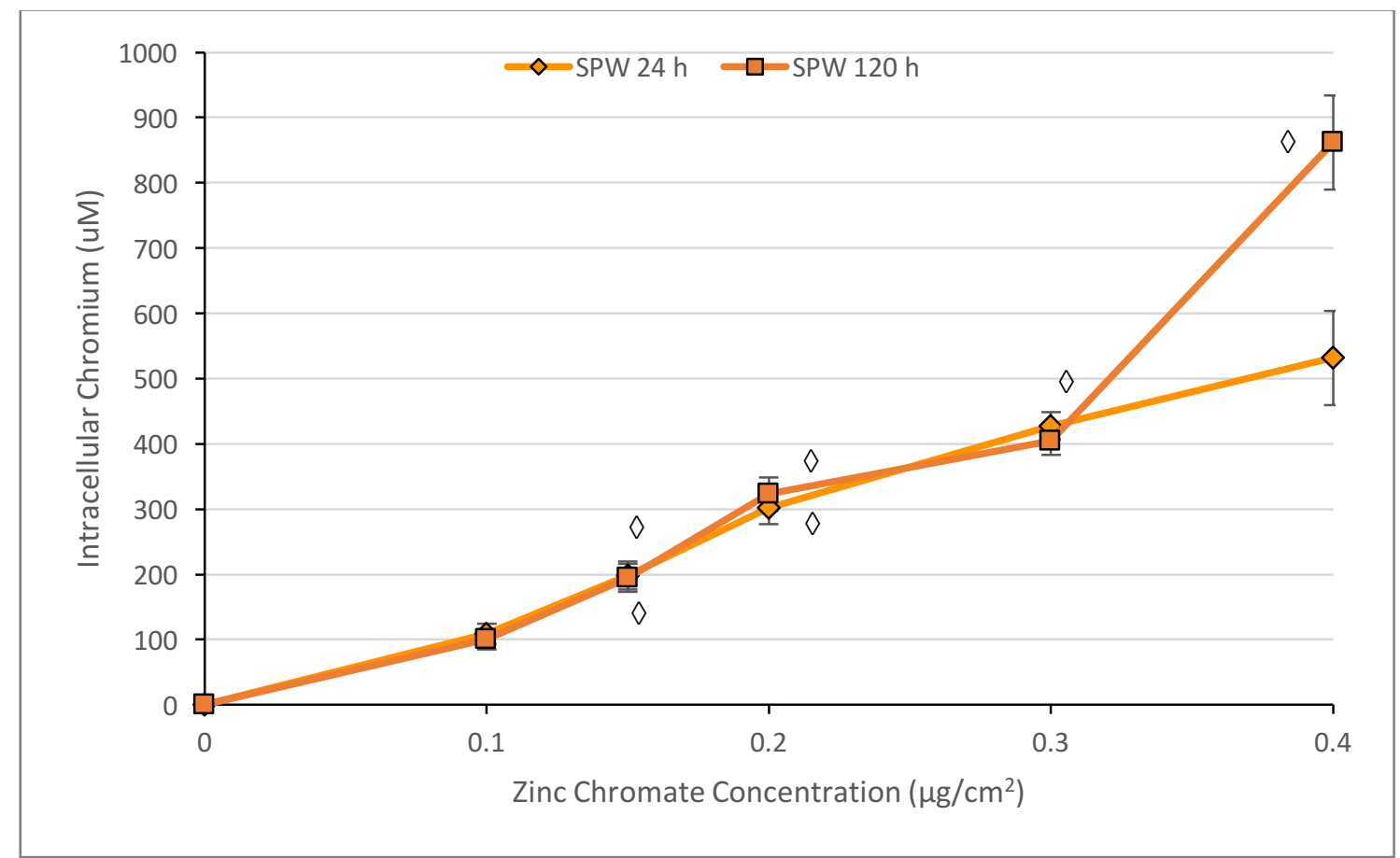

Figure 11: Intracellular chromium concentration $(\mu \mathrm{M})$ in sperm whale skin fibroblasts after 24 and 120 hours of exposure at treatment administrations. Mean $\pm \mathrm{SEM}, \mathrm{N}=3$. *All treatments significantly different from control (Student t-test, $p<0.05$ ). $\diamond$ Significantly different from bowhead whale lung cells (Student t-test, $p<0.05$ ). 


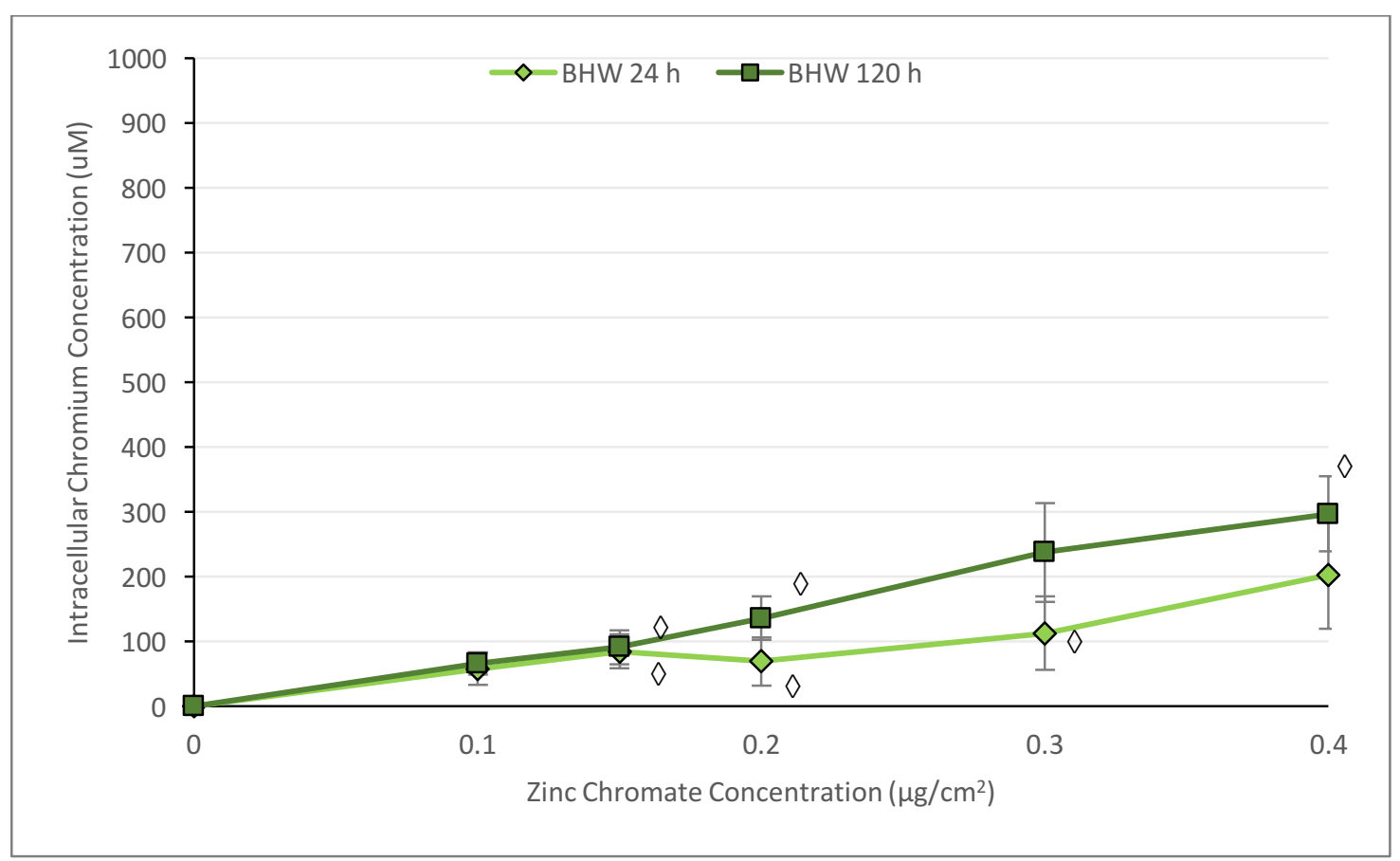

Figure 12: Intracellular chromium concentration $(\mu \mathrm{M})$ in bowhead whale lung fibroblasts after 24 and 120 hours of exposure at treatment administrations. Mean $\pm \mathrm{SEM}, \mathrm{N}=3$. *All treatments significantly different from control (Student t-test, $p<0.05) \diamond$ Significantly different from sperm whale skin cells (Student t-test, $p<0.05$ ). 


\section{DISCUSSION}

Hexavalent chromium $[\mathrm{Cr}(\mathrm{VI})]$ is a known carcinogen with widespread environmental and occupational exposure risks. The mechanism of $\mathrm{Cr}(\mathrm{VI})$ carcinogenesis remains to be fully understood, although the prevailing theory implicates $\mathrm{Cr}(\mathrm{VI})$-induced chromosomal instability (CIN). However, little is known about how $\mathrm{Cr}(\mathrm{VI})$ induces numerical instability. Aneuploidy is characterized by loss or gain of whole chromosomes per cell and it is the most common form of

chromosomal instability observed in cancers (Chan, 2011; Compton, 2011). One proposed mechanism by which numerical instability arises in the genome is through centrosome amplification (Brinkley, 2001; Compton, 2011; D'Assoro, Lingle, \& Salisbury, 2002; Ganem, Godinho, \& Pellman, 2009). Centrosome amplification has been observed in a wide range of solid and hematological cancers and has been identified as an early event in carcinogenesis (Chan, 2011; S. S. Wise \& Wise, 2010). Dividing cells containing supernumerary centrosomes can form multipolar mitoses which lead to improper chromosome segregation to daughter cells and result in aneuploidy. This study investigates centrosome amplification and aneuploidy after $\mathrm{Cr}(\mathrm{VI})$ exposure to build on 
previous work that shows these are potential keys to its carcinogenic mechanism.

Previous studies in the Wise laboratory demonstrate that particulate $\mathrm{Cr}(\mathrm{VI})$ causes significant aneuploidy in human lung fibroblasts which correlates with increasing centrosome amplification over time and increasing concentrations (Holmes et al., 2010; Martino et al., 2015). Whales are long-lived air breathers and are exposed to $\mathrm{Cr}(\mathrm{VI})$ (C. F. Wise et al., 2015; J. P. Wise, Sr. et al., 2009), however the rates of cancer in these animals appear to be much lower than in humans (Caulin \& Maley, 2011). Comparative investigations between human and whale cells revealed that while $\mathrm{Cr}(\mathrm{VI})$ is cytotoxic and genotoxic to both species, whale cells were more resistant to cytotoxicity and to structural chromosome damage compared to human cells (Li Chen et al., 2012; Li Chen et al., 2009). However, no previous studies have investigated numerical chromosome instability or centrosome amplification in whales. Interspecies differences in these key promoters of carcinogenesis can illuminate the mechanism of $\mathrm{Cr}(\mathrm{VI})$-induced genomic instability. Here we have found that whale cells are resistant to $\mathrm{Cr}(\mathrm{VI})$ induced aneuploidy, spindle assembly checkpoint bypass, and they have low rates of centrosome amplification which do not increase after $\mathrm{Cr}(\mathrm{VI})$ exposure.

Cytotoxicity assays show administered concentrations of $0.2,0.3$, and 0.4 $\mu \mathrm{g} / \mathrm{cm}^{2}$ zinc chromate cause statistically significant decreases in colony formation compared to control in both sperm whale and bowhead whale cell lines after 120 hours of exposure. Zinc chromate at these levels was cytotoxic to sperm whale skin fibroblasts after 24 hours of exposure, whereas bowhead whales showed 
significant cytotoxicity after 24 hours only at the highest concentration of 0.4 $\mu \mathrm{g} / \mathrm{cm}^{2}$. The difference in survival between 24 and 120 hours was significant in sperm whales at $0.1,0.2,0.3$, and $0.4 \mu \mathrm{g} / \mathrm{cm}^{2}$ zinc chromate concentrations, however zinc chromate was not significantly more toxic to bowhead whale cells after 120 hours compared to 24 hours at the same concentration. Percent survival relative to control was not significantly different between cell lines, except at the highest concentration (Student's t-test, $p>0.05$ ). At both time points sperm whale cells were more sensitive to cytotoxicity upon $0.4 \mu \mathrm{g} / \mathrm{cm}^{2}$ zinc chromate administration.

This is the first study of $\mathrm{Cr}(\mathrm{VI})$ cytotoxicity in whale cells after 120 hours exposure, and the first results in whale cells for zinc chromate. However, relative survival after 24 hours shown here are in line with published cytotoxicity in sperm whale skin fibroblasts after 24 hour treatments of similar levels of lead chromate, another particulate form of $\mathrm{Cr}(\mathrm{VI})$ (J. P. Wise, Sr. et al., 2011). At similar administered concentrations of lead chromate, zinc chromate appears to induce a similar reduction in survival in sperm whale cells. Concentrations of 0.1 and 0.5 $\mu \mathrm{g} / \mathrm{cm}^{2}$ lead chromate induce 86 and $63 \%$ relative survival (J. P. Wise, Sr. et al., 2011) while 0.1 and $0.4 \mu \mathrm{g} / \mathrm{cm}^{2}$ zinc chromate induce $89 \%$ and $51 \%$ relative survival after 24 hours.

While sperm whale cell survival decreased after 120 hours of exposure, intracellular chromium concentrations were not significantly increased after 120 hours compared to 24 hours for either cell line, as determined by Student t-tests. Inter-experimental variation between atomic absorption spectrometry runs was 
observed and the precision of these measurements will continue to be assessed. Since intracellular chromium levels increase with administered concentration, it is apparent that the cell is not saturated with chromium at lower experimental concentrations, and it is expected that with prolonged exposure time the cell continues to uptake chromium, especially as it is brought out of solution by binding to intracellular molecules. It is possible that prolonged exposure to low intracellular chromium causes increased cytotoxicity at 120 hours.

Aneuploidy was evaluated after zinc chromate treatment in sperm whale and bowhead whale cells. Metaphase cells were harvested after demecolcineinduced arrest and chromosomes were counted in at least 100 metaphases. Notably, after 120 hours of exposure to $0.4 \mu \mathrm{g} / \mathrm{cm}^{2}$ zinc chromate, sperm whale cells experienced cell cycle arrest, failing to yield enough metaphases to analyze. No treatment condition produced aneuploidy in excess of control populations. Bowhead whale cells had slightly higher background aneuploidy compared to sperm whale cells. Published results show that $0.1,0.15$, and $0.2 \mu \mathrm{g} / \mathrm{cm}^{2}$ zinc chromate caused $28 \%, 40 \%$, and $44 \%$ aneuploidy in human lung cells, which is significantly higher than the background rates of $8-13 \%$ (Holmes et al., 2010). Our current study suggests that whale cells are resistant to $\mathrm{Cr}(\mathrm{VI})$-induced numerical chromosome instability. There are several possible mechanisms by which aneuploidy occurs including failure of cytokinesis, spindle assembly checkpoint bypass, and centrosome amplification. Failure of cytokinesis will produce tetraploid cells, but asymmetrical division of chromosomes causes imbalances in gene dosing that may be important to carcinogenesis. Thus, we 
also evaluated spindle assembly checkpoint bypass and centrosome amplification as these phenotypes are observed in $\mathrm{Cr}(\mathrm{VI})$-treated cells and correlate with numerical CIN.

Spindle assembly checkpoint protects against aneuploidy by preventing progression to anaphase until all kinetochores are properly attached to spindle fibers. Centromere spreading, premature centromere division, and premature anaphase are consequences of particulate $\mathrm{Cr}(\mathrm{VI})$ exposure in human lung fibroblasts (Holmes et al., 2010). These phenomena produced in metaphasearrested cells are evidence of spindle assembly checkpoint bypass. Neither sperm whale nor bowhead whale cells showed evidence of spindle assembly checkpoint bypass at any treatment conditions, demonstrating that these whale species somehow maintain regulation of spindle assembly checkpoint proteins under conditions in which human lung cells do not.

Aberrant centrosome numbers are commonly observed in most cancers and is also seen in pre-neoplasias (Chan, 2011). Centrosome amplification increases with tumor aggressiveness and correlates with poor prognoses (Chan, 2011). In addition to $\mathrm{Cr}(\mathrm{VI})$, arsenic also induces centrosome amplification (Holmes \& Wise, 2010; S. S. Wise \& Wise, 2010). Thus, centrosome amplification is an important cancer phenotype as well as a potential key mechanism of metal carcinogenesis. Normal interphase cells have 1 or 2 centrosomes and $\mathrm{Cr}(\mathrm{VI})$ exposure has been shown to cause supernumerary centrosomes (Holmes \& Wise, 2010; Holmes et al., 2010; Martino et al., 2015; S. S. Wise \& Wise, 2010). The mechanism that seems to best fit $\mathrm{Cr}(\mathrm{VI})$-induced 
amplification is abnormal reduplication of centrosomes (Martino et al., 2015). Normally, centrosomes are restricted to one cycle of duplication during $S$ phase (Tsou \& Stearns, 2006a, 2006b). However, DNA-damaging treatments produce centrosome amplification during prolonged G2 phase (Dodson et al., 2004; Inanc et al., 2010). Thus, centrosome overduplication can first be observed in interphase cells. Zinc chromate treatment did not induce centrosome amplification in bowhead or sperm whale interphase cells at any treatment concentration or time point. The mechanisms of centrosome amplification are unknown. Hypotheses center on protein dysregulations that allow the centrosome duplication cycle to become desynchronized with cell cycle progression (Agircan et al., 2014; Bolgioni \& Ganem, 2016; Hatano \& Sluder, 2012). The fact that zinc chromate does not cause centrosome overduplication in whale cells make them a useful comparative model for studying the molecular components that regulate centrosome duplication.

The point at which centrosome amplification becomes critical is during mitosis. Multipolar spindle formations can cause aberrant segregation of chromosomes, resulting in aneuploidy (Ganem et al., 2009). Cells can overcome multipolar arrangements by clustering centrosomes to form pseudo-bipolar spindle poles (Ganem et al., 2009). However, this coping mechanism does not ensure faithful chromosome segregation because excess centrosomes block one another and may also form erroneous kinetochore attachments before moving into bipolar positions. Normal mitotic cells have 2 centrosomes. During our study, no zinc chromate treatment conditions caused aberrant centrosomes to elevate 
above control percentages in either cell line. Consistent with the metaphase assays, $0.4 \mu \mathrm{g} / \mathrm{cm}^{2}$ zinc chromate caused depressed mitotic numbers in sperm whale cells, suggesting cell cycle arrest. Background levels of centrosome amplification were low in both mitotic and interphase whale cells.

It is possible that whale cells with centrosome amplification are culled by apoptosis. However, cytotoxicity data for bowhead whale lung fibroblasts reveal only mild decreases in relative survival with increasing zinc chromate concentrations. Mitotic arrest seen at the high end of our experimental concentrations could be a strategy to prevent aberrant cells from dividing and producing aneuploid cells, however research has identified G2 arrest to be causative in centrosome amplification and these data prove that interphase centrosome amplification does not increase in whale cells exposed to $\mathrm{Cr}(\mathrm{VI})$. Thus, these data suggest that whales have evolved strategies to combat chromosome instability induced by $\mathrm{Cr}(\mathrm{VI})$ which are lacking in human cells.

Comparative studies show that chromium uptake differs between whale and human cells. These comparisons need to repeated using zinc chromate, however lead chromate experiments show that human cells achieve higher intracellular concentrations than whale cells after equal administrations. Li Chen, et al., (2012) corrected for differential uptake and showed that uptake differences did not fully explain clastogenic differences such as structural chromosome damage (Li Chen et al., 2012). Considering extremely low occurrences of centrosome amplification in whale cells despite demonstrated cytotoxicity and 
apparent cell cycle arrest, further studies should explore the effect of uptake on human versus whale cell centrosomes.

Whale cell resistance to $\mathrm{Cr}(\mathrm{VI})$-induced centrosome amplification and numerical chromosome instability highlights the important link between these two phenotypes which are proposed to underlie carcinogenesis. Species comparisons between human and whales can help to elucidate the molecular mechanisms of $\mathrm{Cr}(\mathrm{VI})$ carcinogenesis. Future studies may benefit from comparisons between whale and human cells. The cause of centrosome amplification is unknown, but a leading hypothesis involves premature reduplication during G2 phase. Human cells have been shown to undergo premature centriole disengagement and premature centrosome separation, which may remove the normal blocking of duplication. (Martino, 2015) Investigating these phenomena in whale cells and comparing regulatory proteins within the centrosome cycle across species can help to pinpoint adaptive strategies that can lead to novel therapeutic targets. 


\section{REFERENCES}

Agency for Toxic Substances and Disease Registry. (2012). Toxicological Profile for Chromium. Atlanta (GA): U.S. Department of Health and Human Services, Public Health Service Retrieved from https://www.ncbi.nlm.nih.gov/pubmed/24049864.

Agircan, F. G., Schiebel, E. \& Mardin, B. R. (2014). Separate to operate: control of centrosome positioning and separation. Philos Trans $R$ Soc Lond B Biol Sci, 369(1650). doi:10.1098/rstb.2013.0461

Bolgioni, A. F. \& Ganem, N. J. (2016). The interplay between centrosomes and the Hippo tumor suppressor pathway. Chromosome Res, 24(1), 93-104. doi:10.1007/s10577-015-9502-8

Brinkley, B. R. (2001). Managing the centrosome numbers game: from chaos to stability in cancer cell division. Trends Cell Biol, 11(1), 18-21.

Browning, C. L., Wise, C. F. \& Wise, J. P., Sr. (2017). Prolonged particulate chromate exposure does not inhibit homologous recombination repair in North Atlantic right whale (Eubalaena glacialis) lung cells. Toxicol Appl Pharmacol, 331, 18-23. doi:10.1016/j.taap.2017.04.006

Caulin, A. F. \& Maley, C. C. (2011). Peto's Paradox: evolution's prescription for cancer prevention. Trends Ecol Evol, 26(4), 175-182. doi:10.1016/j.tree.2011.01.002

Chan, J. Y. (2011). A clinical overview of centrosome amplification in human cancers. Int J Biol Sci, 7(8), 1122-1144.

Compton, D. A. (2011). Mechanisms of aneuploidy. Curr Opin Cell Biol, 23(1), 109-113. doi:10.1016/j.ceb.2010.08.007

Conduit, P. T., Wainman, A. \& Raff, J. W. (2015). Centrosome function and assembly in animal cells. Nat Rev Mol Cell Biol, 16(10), 611-624. doi:10.1038/nrm4062

D'Assoro, A. B., Lingle, W. L. \& Salisbury, J. L. (2002). Centrosome amplification and the development of cancer. Oncogene, 21(40), 6146-6153. doi:10.1038/sj.onc.1205772

Darling, S., Fielding, A. B., Sabat-Pospiech, D., Prior, I. A. \& Coulson, J. M. (2017). Regulation of the cell cycle and centrosome biology by deubiquitylases. Biochem Soc Trans, 45(5), 1125-1136. doi:10.1042/BST20170087 
Dodson, H., Bourke, E., Jeffers, L. J., Vagnarelli, P., Sonoda, E., Takeda, S., Morrison, C. (2004). Centrosome amplification induced by DNA damage occurs during a prolonged $\mathrm{G} 2$ phase and involves ATM. EMBO J, 23(19), 3864-3873. doi:10.1038/sj.emboj.7600393

Douthwright, S. \& Sluder, G. (2014). Link between DNA damage and centriole disengagement/reduplication in untransformed human cells. J Cell Physiol, 229(10), 1427-1436. doi:10.1002/jcp.24579

Fukasawa, K. (2005). Centrosome amplification, chromosome instability and cancer development. Cancer Lett, 230(1), 6-19.

doi:10.1016/j.canlet.2004.12.028

Ganem, N. J., Godinho, S. A. \& Pellman, D. (2009). A mechanism linking extra centrosomes to chromosomal instability. Nature, 460(7252), 278-282. doi:10.1038/nature08136

Geisler, C.-D. \& Schmidt, D. (1992). An Overview of Chromium in the Marine Environment. Deutsche hydrographische Zeitschrift, 44, 185-196.

Godinho, S. A. \& Pellman, D. (2014). Causes and consequences of centrosome abnormalities in cancer. Philos Trans R Soc Lond B Biol Sci, 369(1650). doi:10.1098/rstb.2013.0467

Hatano, T. \& Sluder, G. (2012). The interrelationship between APC/C and Plk1 activities in centriole disengagement. Biol Open, 1(11), 1153-1160. doi:10.1242/bio.20122626

Holmes, A. L. \& Wise, J. P. (2010). Mechanisms of metal-induced centrosome amplification. Biochem Soc Trans, 38(6), 1687-1690. doi:10.1042/BST0381687

Holmes, A. L., Wise, S. S., Pelsue, S. C., Aboueissa, A. M., Lingle, W., Salisbury, J., Wise, J. P., Sr. (2010). Chronic exposure to zinc chromate induces centrosome amplification and spindle assembly checkpoint bypass in human lung fibroblasts. Chem Res Toxicol, 23(2), 386-395. doi:10.1021/tx900360w

Holmes, A. L., Wise, S. S., Sandwick, S. J., Lingle, W. L., Negron, V. C., Thompson, W. D. \& Wise, J. P., Sr. (2006). Chronic exposure to lead chromate causes centrosome abnormalities and aneuploidy in human lung cells. Cancer Res, 66(8), 4041-4048. doi:10.1158/0008-5472.CAN-053312

Holmes, A. L., Wise, S. S. \& Wise, J. P., Sr. (2008). Carcinogenicity of hexavalent chromium. Indian J Med Res, 128(4), 353-372.

Inanc, B., Dodson, H. \& Morrison, C. G. (2010). A centrosome-autonomous signal that involves centriole disengagement permits centrosome duplication in G2 phase after DNA damage. Mol Biol Cell, 21(22), 38663877. doi:10.1091/mbc.E10-02-0124 
Jacobs, J. \& Testa, S. (2005). Overview of Chromium in the Environment: Background and History. In J. Guertin, J. Jacobs, \& C. Avakian (Eds.), Chromium (VI) Handbook (pp. 1-22): CRC Press.

Johnson, J., Schewel, L. \& Graedel, T. E. (2006). The contemporary anthropogenic chromium cycle. Environ Sci Technol, 40(22), 7060-7069.

Kao, Y. C., Jheng, J. R., Pan, H. J., Liao, W. Y., Lee, C. H. \& Kuo, P. L. (2017). Elevated hydrostatic pressure enhances the motility and enlarges the size of the lung cancer cells through aquaporin upregulation mediated by caveolin-1 and ERK1/2 signaling. Oncogene, 36(6), 863-874. doi:10.1038/onc.2016.255

Karki, M., Keyhaninejad, N. \& Shuster, C. B. (2017). Precocious centriole disengagement and centrosome fragmentation induced by mitotic delay. Nat Commun, 8, 15803. doi:10.1038/ncomms15803

Kaseda, K., McAinsh, A. D. \& Cross, R. A. (2012). Dual pathway spindle assembly increases both the speed and the fidelity of mitosis. Biol Open, 1(1), 12-18. doi:10.1242/bio.2011012

Keane, M., Semeiks, J., Webb, A. E., Li, Y. I., Quesada, V., Craig, T., de Magalhaes, J. P. (2015). Insights into the evolution of longevity from the bowhead whale genome. Cell Rep, 10(1), 112-122.

doi:10.1016/j.celrep.2014.12.008

Kondo, K., Takahashi, Y., Ishikawa, S., Uchihara, H., Hirose, Y., Yoshizawa, K., Monden, Y. (2003). Microscopic analysis of chromium accumulation in the bronchi and lung of chromate workers. Cancer, 98(11), 2420-2429. doi:10.1002/cncr.11818

Langard, S. \& Vigander, T. (1983). Occurrence of lung cancer in workers producing chromium pigments. Br J Ind Med, 4O(1), 71-74.

Levine, M. S., Bakker, B., Boeckx, B., Moyett, J., Lu, J., Vitre, B., Holland, A. J. (2017). Centrosome Amplification Is Sufficient to Promote Spontaneous Tumorigenesis in Mammals. Dev Cell, 40(3), 313-322 e315. doi:10.1016/j.devcel.2016.12.022

Levy, L. S., Martin, P. A. \& Bidstrup, P. L. (1986). Investigation of the potential carcinogenicity of a range of chromium containing materials on rat lung. $\mathrm{Br}$ $J$ Ind Med, 43(4), 243-256.

Li Chen, T., LaCerte, C., Wise, S. S., Holmes, A., Martino, J., Wise, J. P., Jr., Wise, J. P., Sr. (2012). Comparative cytotoxicity and genotoxicity of particulate and soluble hexavalent chromium in human and sperm whale (Physeter macrocephalus) skin cells. Comp Biochem Physiol C Toxicol Pharmacol, 155(1), 143-150. doi:10.1016/j.cbpc.2011.03.011 
Li Chen, T., Wise, S. S., Holmes, A., Shaffiey, F., Wise, J. P., Jr., Thompson, W. D., Wise, J. P., Sr. (2009). Cytotoxicity and genotoxicity of hexavalent chromium in human and North Atlantic right whale (Eubalaena glacialis) lung cells. Comp Biochem Physiol C Toxicol Pharmacol, 150(4), 487-494. doi:10.1016/j.cbpc.2009.07.004

Martino, J., Holmes, A. L., Xie, H., Wise, S. S. \& Wise, J. P., Sr. (2015). Chronic Exposure to Particulate Chromate Induces Premature Centrosome Separation and Centriole Disengagement in Human Lung Cells. Toxicol Sci, 147(2), 490-499. doi:10.1093/toxsci/kfv146

National Institute for Occupational Safety and Health, C. f. D. C. a. P., U.S. Department of Health and Human Services. (2013). Occupational Exposure to Hexavalent Chromium: Criteria for a Recommended Standard. (2013-128). Washington, D.C.: Author.

Nigg, E. A., Cajanek, L. \& Arquint, C. (2014). The centrosome duplication cycle in health and disease. FEBS Lett, 588(15), 2366-2372. doi:10.1016/j.febslet.2014.06.030

Nigg, E. A. \& Stearns, T. (2011). The centrosome cycle: Centriole biogenesis, duplication and inherent asymmetries. Nat Cell Biol, 13(10), 1154-1160. doi:10.1038/ncb2345

Occupational Safety and Health Administration. (2006). Occupational exposure to hexavalent chromium. Final rule.

Tchounwou, P. B., Yedjou, C. G., Patlolla, A. K. \& Sutton, D. J. (2012). Heavy metal toxicity and the environment. EXS, 101,133-164. doi:10.1007/9783-7643-8340-4_6

Tokuda, S., Kim, Y. H., Matsumoto, H., Muro, S., Hirai, T., Mishima, M. \& Furuse, M. (2015). Effects of Hydrostatic Pressure on Carcinogenic Properties of Epithelia. PLoS One, 10(12), e0145522. doi:10.1371/journal.pone.0145522

Tsou, M. F. \& Stearns, T. (2006a). Controlling centrosome number: licenses and blocks. Curr Opin Cell Biol, 18(1), 74-78. doi:10.1016/j.ceb.2005.12.008

Tsou, M. F. \& Stearns, T. (2006b). Mechanism limiting centrosome duplication to once per cell cycle. Nature, 442(7105), 947-951. doi:10.1038/nature04985

Wang, G., Jiang, Q. \& Zhang, C. (2014). The role of mitotic kinases in coupling the centrosome cycle with the assembly of the mitotic spindle. J Cell Sci, 127(Pt 19), 4111-4122. doi:10.1242/jcs.151753

Wise, C. F., Wise, S. S., Thompson, W. D., Perkins, C. \& Wise, J. P., Sr. (2015). Chromium Is Elevated in Fin Whale (Balaenoptera physalus) Skin Tissue and Is Genotoxic to Fin Whale Skin Cells. Biol Trace Elem Res, 166(1), 108-117. doi:10.1007/s12011-015-0311-x 
Wise, J. P., Sr., Payne, R., Wise, S. S., LaCerte, C., Wise, J., Gianios, C., Jr., Kerr, I. (2009). A global assessment of chromium pollution using sperm whales (Physeter macrocephalus) as an indicator species. Chemosphere, 75(11), 1461-1467. doi:10.1016/j.chemosphere.2009.02.044

Wise, J. P., Sr., Wise, S. S., LaCerte, C., Wise, J. P., Jr. \& Aboueissa, A. M. (2011). The genotoxicity of particulate and soluble chromate in sperm whale (Physeter macrocephalus) skin fibroblasts. Environ Mol Mutagen, 52(1), 43-49. doi:10.1002/em.20579

Wise, S. S., Holmes, A. L., Xie, H., Thompson, W. D. \& Wise, J. P., Sr. (2006). Chronic exposure to particulate chromate induces spindle assembly checkpoint bypass in human lung cells. Chem Res Toxicol, 19(11), 14921498. doi:10.1021/tx0601410

Wise, S. S. \& Wise, J. P. (2010). Aneuploidy as an early mechanistic event in metal carcinogenesis. Biochem Soc Trans, 38(6), 1650-1654. doi:10.1042/BST0381650

Wise, S. S. \& Wise, J. P., Sr. (2012). Chromium and genomic stability. Mutat Res, 733(1-2), 78-82. doi:10.1016/j.mrfmmm.2011.12.002

Xie, H., Holmes, A. L., Wise, S. S., Huang, S., Peng, C. \& Wise, J. P., Sr. (2007). Neoplastic transformation of human bronchial cells by lead chromate particles. Am J Respir Cell Mol Biol, 37(5), 544-552. doi:10.1165/rcmb.2007-00580C

Xie, H., Wise, S. S. \& Wise, J. P., Sr. (2008). Deficient repair of particulate hexavalent chromium-induced DNA double strand breaks leads to neoplastic transformation. Mutat Res, 649(1-2), 230-238.

doi:10.1016/j.mrgentox.2007.09.008 


\title{
CURRICULUM VITA
}

\author{
Jennifer Haruka Toyoda \\ Email Address: j.toyoda@louisville.edu
}

\section{Education}

\begin{tabular}{|c|c|c|c|}
\hline INSTITUTION & $\begin{array}{c}\text { DEGREE } \\
\text { (if applicable) }\end{array}$ & DATES & FIELD OF STUDY \\
\hline Smith College & & $1997-2000$ & Liberal Arts \\
\hline Transylvania University & & 1998 & Liberal Arts \\
\hline Greenfield Community College & & $2000-2002$ & Liberal Arts \\
\hline University of Massachusetts & B.A. & $2002-2005$ & Studio Art \\
\hline $\begin{array}{l}\text { University of Southern } \\
\text { Mississippi }\end{array}$ & & 2010 & $\begin{array}{l}\text { Gulf Coast Research } \\
\text { Laboratory Summer } \\
\text { Program }\end{array}$ \\
\hline University of Kentucky & B.S. & $2008-2011$ & Biology \\
\hline University of Louisville & & 206-Present & $\begin{array}{l}\text { Pharmacology \& } \\
\text { Toxicology }\end{array}$ \\
\hline
\end{tabular}

\section{Research Experience}

\begin{tabular}{l|c|l|l|l}
\hline \multicolumn{1}{c|}{ POSITON } & DATES & \multicolumn{1}{c|}{ FIELD } & INSTITUTION & $\begin{array}{l}\text { SUPERVIS } \\
\text { OR }\end{array}$ \\
\hline $\begin{array}{l}\text { Independent } \\
\text { study/Lab Assistant }\end{array}$ & $\begin{array}{c}2009- \\
2011\end{array}$ & Ecology & University of Kentucky & $\begin{array}{l}\text { Dr. Phillip } \\
\text { Crowley } \\
\text { Graduate Student }\end{array}$ \\
$\begin{array}{c}2016- \\
\text { Present }\end{array}$ & $\begin{array}{l}\text { Pharmacology \& } \\
\text { Toxicology }\end{array}$ & University of Louisville & $\begin{array}{l}\text { Dr. John P. } \\
\text { Wise, Sr. }\end{array}$
\end{tabular}




\section{Academic and Professional Awards}

2017 Graduate Student Council Research Award

2018 Graduate Student Council Research Award

\section{Academic and Professional Memberships}

Department of Pharmacology and Toxicology Student Organization - Class

representative

Society of Toxicology - Member Ohio Valley Regional Group, Metals,

Carcinogenesis

\section{Presentations, Posters and Abstracts}

Croom-Pérez, T.J., Toyoda, J.H., Wise, S. S. and Wise, Sr., J.P. Chronic Exposure to Particulate Hexavalent Chromium Induces Centrosome Abnormalities and Disrupts Mitosis in both Sea Turtle and Alligator Primary Lung Cells. Presented at the Ohio Valley Chapter of the Society of Toxicology (OVSOT) annual meeting, December, 2017.

Croom-Pérez, T.J., Toyoda, J.H., Wise, S. S. and Wise, Sr., J. P. Chronic Exposure to Particulate Hexavalent Chromium Induces Centrosome Abnormalities and Disrupts Mitosis in both Sea Turtle and Alligator Primary Lung Cells. Toxicological Sciences, 150(1): 480, 2018.

Toyoda, J.H., Martino, J. and Wise, Sr., J. P. Mechanisms of Hexavalent Chromium-Induced Centriole Disengagement and Centrosome Amplification. Poster presented at Graduate Student Regional Research Conference, University of Louisville, 2018.

Toyoda, J.H., Martino, J., Speer, R.M. and Wise Sr., J. P. Mechanisms of Hexavalent Chromium-Induced Centriole Disengagement and Centrosome Amplification. Poster presented at Research!Louisville, University of Louisville, 2017.

Toyoda, J.H. and Shenoy, K. In Utero Exposure to Endocrine Disruptors and Mate Choice in Female Guppies. Poster presented at Showcase of Undergraduate Scholars, University of Kentucky, 2011.

Shenoy, K. and Toyoda, J.H. Prenatal Exposure to Atrazine: Latent Effects on Mating Behaviors in Guppies. Oral presentation, Society for Integrative and Comparative Biology, 2012 annual meeting, Charleston, SC 